\title{
Immunoglobulin G4-Related Disease: What an Allergist Should Know
}

\author{
Carballo I', González-Quintela $A^{1,2}$, Sopeña $B^{1}$, Vidal $C^{3}$ \\ 'Department of Internal Medicine, Complejo Hospitalario Universitario de Santiago, University of Santiago de Compostela, Santiago de \\ Compostela, Spain \\ ${ }^{2}$ Spanish Network for Addictive Disorders (Red de Trastornos Adictivos, RD16/0017/0018), Spain \\ ${ }^{3}$ Department of Allergy, Complejo Hospitalario Universitario de Santiago, University of Santiago de Compostela, Santiago de Compostela, Spain
}

J Investig Allergol Clin Immunol 2021; Vol. 31(3): 212-227

doi: 10.18176/jiaci.0633

\begin{abstract}
Immunoglobulin G4-related disease (IgG4-RD) is a fibroinflammatory disorder that begins in 1 or more organs as inflammatory tumors that progress toward fibrosis. It is often accompanied by elevated serum IgG4. IgG4-RD was first described in 2003 as a new concept encompassing a number of immunoallergic diseases that had previously been considered unrelated. IgG4-RD mainly affects middleaged and older men. It consists of upregulation and expansion of CD4+ cytotoxic T lymphocytes, oligoclonal plasmablasts, and other inflammatory cells that infiltrate affected tissues and induce inflammation, organ dysfunction, and fibrosis. Symptoms depend on the location, severity, and extent of the disease. Virtually any organ can be affected, including the pancreas, salivary glands, lacrimal glands, thyroid gland, retro-orbital tissue, lymph nodes, retroperitoneum, mediastinum, lung, kidney, aorta, serosal surfaces, and meninges. Patients with widespread disease may present general symptoms. At least 30\%-40\% of patients are atopic or display atopic traits such as eosinophilia and elevated serum IgE levels. Additional laboratory features include increased serum IgG4 concentrations, increased blood IgG4-plasmablasts, hypergammaglobulinemia, and hypocomplementemia. Diagnosis of IgG4-RD is based on a clinicopathological correlation. Lymphoplasmacytic infiltrate with abundant IgG4-positive plasma cells, storiform-type fibrosis, obliterative phlebitis, and tissue eosinophilia are the pathological hallmarks. Therapy for lgG4-RD is based primarily on corticosteroids but may include additional immunomodulatory drugs and monoclonal antibodies such as rituximab. In individuals with allergic features, IgG4-RD should be suspected when a history of unexplained swelling is observed in 1 or more organs, particularly if they respond to corticosteroids and the patients are men in the sixth decade of life and beyond.
\end{abstract}

Key words: Immunoglobulin G4-related disease. Allergy. Immunoglobulin G. IgG4. Immunoglobulin E. Eosinophils. Inflammation. Fibrosis.

\section{Resumen}

La enfermedad relacionada con la inmunoglobulina G4 (ER-lgG4) afecta a uno o varios órganos, produciendo tumores inflamatorios que evolucionan a fibrosis, y elevación de la lgG4 en suero. Se describió en 2003 como una entidad que engloba numerosas patologías de naturaleza inmuno-alérgica, previamente consideradas idiopáticas. Afecta principalmente a varones a partir de mediana edad. Fisiopatológicamente se produce un aumento y expansión de linfocitos T citotóxicos CD4+, plasmablastos oligoclonales y otras células inflamatorias, que infiltran los tejidos produciendo inflamación, disfunción orgánica y fibrosis. Los síntomas pueden llegar a ser generales, dependen de la localización, gravedad y extensión de la enfermedad. Cualquier órgano puede verse afectado: páncreas, glándulas salivales, glándulas lacrimales, tiroides, órbita, ganglios linfáticos, retroperitoneo, mediastino, pulmón, riñón, aorta, serosas y meninges. Al menos un 30-40\% de los pacientes presentan rasgos atópicos como eosinofilia o elevación de la lgE en suero. Otros datos frecuentes son el aumento de la lgG4 sérica, de los plasmablastos lgG4+ en sangre, hipergammaglobulinemia e hipocomplementemia. El diagnóstico se basa en una adecuada correlación clínico-patológica, destacando en la histología un infiltrado linfoplasmocitario con abundantes células plasmáticas lgG4+, fibrosis estoriforme, flebitis obliterante y eosinofilia. El tratamiento fundamental son los corticoides pero puede incluir inmunomoduladores y anticuerpos monoclonales como el rituximab. En pacientes de perfil alérgico, la ER-IgG4 se debe sospechar ante un cuadro clínico de tumoración o agrandamiento inexplicable de uno o varios órganos, particularmente si responde al tratamiento con corticoides y si se trata de varones a partir de la $6^{a}$ década de la vida.

Palabras clave: Enfermedad relacionada con la inmunoglobulina G4. Alergia. Inmunoglobulina G. IgG4. Inmunoglobulina E. Eosinófilos. Inflamación. Fibrosis. 


\section{Introduction and History of IgG4-Related Disease}

Immunoglobulin G4-related disease (IgG4-RD) is a clinicopathological entity that produces inflammation and fibrosis of 1 or more organs. It is characterized by a lymphoplasmacytic infiltrate of IgG4-positive plasma cells, a variable degree of fibrosis with a typical storiform pattern, and elevated serum concentrations of IgG4 in most patients [1]. The disease was first described in 2003 by Kamisawa et al [2], although 2 years before, Hamano et al [3] had already reported the association between increased serum IgG4 concentrations and so-called autoimmune pancreatitis. The authors suggested the concept of IgG4-RD [2], which includes many previously unrelated diseases, such as autoimmune pancreatitis, Riedel thyroiditis, Mikulicz syndrome, and retroperitoneal fibrosis [1] (Table 1). The histopathological diagnostic criteria for IgG4RD were established in 2012 [10], and the International Consensus Guidance Statement on the Management and Treatment of IgG4-RD was published in 2015 [11]. Finally, The American College of Rheumatology (ACR)/European League Against Rheumatism (EULAR) Classification criteria for IgG4-related disease were presented in 2018 and published in December 2019 [12].

Table 1. Diseases and Syndromes That Can Be Included in IgG4-Related Disease

Diseases and Syndromes

IgG4-R pachymeningitis/idiopathic hypertrophic

pachymeningitis/cerebritis/hypophysitis/neuritis [4,5]

IgG4-R ophthalmic disease/orbital inflammation/pan-orbital inflammation/orbital myositis [4]

IgG4-R dacryoadenitis/scleritis/uveitis [4,5]

IgG4-R inflammatory pseudotumour [4]

Eosinophilic angiocentric fibrosis [4]

IgG4-R chronic rhinosinusitis [6]

IgG4-R sialadenitis/sialadenitis and dacryoadenitis/Mikulicz disease [4]

IgG4-R submandibular gland disease/Küttner tumor [4]

IgG4-RD of the tongue/palatine tonsil [5]

IgG4-RD of the soft tissues of the head and neck/idiopathic cervical fibrosis [4]

IgG4-R thyroid disease/Riedel thyroiditis [4]

IgG4-RD of the supraglottis/trachea [5]

IgG4-R mediastinitis/fibrosing mediastinitis/thymus disease [4,5]

IgG4-R mastitis/uterus disease [4,5]

IgG4-R lung disease/interstitial pneumonitis/pleuritis [4,5]

IgG4-R pericarditis/heart disease [4,5]

IgG4-R aortitis/inflammatory aortic aneurysm/periaortitis/periarteritis [4]

IgG4-R esophagitis/gastritis/enteritis/colitis [7]

IgG4-R hepatopathy/cholecystitis/sclerosing cholangitis/spleen disease [4,5]

IgG4-R pancreatitis/autoimmune pancreatitis type 1/lymphoplasmacytic sclerosing pancreatitis [4]

IgG4-R retroperitoneal disease/retroperitoneal fibrosis/Ormond disease [4]

IgG4-R mesenteritis/sclerosing mesenteritis [4]

IgG4-R kidney disease/glomerulonephritis/idiopathic hypocomplementemic tubulointerstitial nephritis [4,5]

IgG4-R renal pyelitis/ureteritis/interstitial cystitis/urethritis/prostatitis/ testicular/paratesticular disease $[4,8]$

IgG4-R lymphadenopathy [4]

IgG4-R arthritis/bone disease/bone marrow disease [5,9]

IgG4-R skin disease/cutaneous pseudolymphoma [4]

IgG4-RD/multifocal fibrosclerosis [4]
Affected Organs

Pachymeninges/brain/hypophysis/nerve

Eye/orbital soft tissue/multiple structures of the orbit/extraocular muscles

Lacrimal glands/sclera/uvea

Any organ (often referred to orbit)

Orbits and upper respiratory tract

Paranasal sinuses

Salivary glands/salivary and lacrimal glands

Submandibular glands

Tongue/palatine tonsil

Soft tissues of the head and neck

Thyroid

Supraglottis/trachea

Mediastinum/thymus

Breast/uterus

Lung/pleura

Pericardium/heart

Aorta/arteries

Esophagus/stomach/small/large intestine

Liver/gallbladder/bile ducts/spleen

Pancreas

Retroperitoneum

Mesentery

Kidney

Renal pelvis/ureter/urinary bladder/urethra/ prostate/testis/paratestis

Lymph node

Joints/bone/bone marrow

Skin

Affecting multiple organs

alt should be noted that every organ of the body can be affected by lgG4-related (IgG4-R) disease. 


\section{Epidemiology of IgG4-Related Disease}

IgG4-RD was first described in Japan, where the prevalence is around 6.3 cases per 100000 people [13]. While it can affect all racial and ethnic groups, prevalence seems to be low or, at least, unknown or underestimated in other countries [7]. The average age at onset is 59 years [13], although a few cases have been reported in children [14]. Males are more frequently affected (56\%) [13], except in cases of head and neck involvement $[15,16]$. In general, women with IgG4-RD are younger, with a higher prevalence of allergic diseases and lower peripheral eosinophils, C-reactive protein and serum IgG4 levels, as well as better prognosis [17].

\section{The IgG4 Molecule and Its Relationship With Allergic Disorders}

IgG4 is the least abundant IgG subclass in humans, representing between $1 \%$ and $10 \%$ of total serum $\mathrm{IgG}$, with a half-life of approximately 21 days [18]. In a series of 413 individuals from a general adult population, the median (IQR) IgG4 concentration was $33 \mathrm{mg} / \mathrm{dL}(14-44 \mathrm{mg} / \mathrm{dL}$ [97.5 percentile, $126 \mathrm{mg} / \mathrm{dL}$ ]) [18]. Serum IgG4 concentrations decrease with age and are higher in males than in females [18].

As with other immunoglobulins, IgG4 is composed of 2 heavy and 2 light chains, although it differs in that its 2 heavy chains can be linked together by noncovalent bonds [19]. Therefore, hemi-IgG4 molecules (1 heavy chain covalently bound to 1 light chain) can be associated with distinct hemi-IgG4 molecules in a process called Fab-arm exchange [19]. As a result, these antibodies have the ability to interact with various antigens simultaneously and are incapable of forming large precipitating immune complexes [19]. On the other hand, the IgG4 molecule has a low affinity for $\mathrm{C} 1 \mathrm{q}$ and cannot activate the classical complement pathway [19].

The role of IgG4 in allergic disorders is well-known. Even though $\operatorname{IgG} 1$ is the initial $\mathrm{IgG}$ subclass involved in allergen exposure, IgG4 is responsible for humoral immune tolerance after prolonged allergenic stimulation, as is the case in allergen immunotherapy [20,21], where IgG4 competes with $\operatorname{IgE}$ and inhibits mast cell degranulation because of the presence of Fc $\gamma \mathrm{RIIb}$ and FceRI receptors on effector cells [21]. IgG4 also competes with IgE by blocking the activation of antigen-presenting $\mathrm{B}$ cells through inhibition of the allergen presentation facilitated by $\operatorname{IgE}$ [22]. Since these responses can also occur in asymptomatic helminth infections or after chronic exposure to high doses of allergens, specific IgG4 may act as a marker of the state of immune tolerance of a patient against a given allergen [23]. In fact, specific IgG4 tests have been used to evaluate allergen immunotherapy [22,24], and allergen-specific IgG4 may indicate development of tolerance in patients with food allergy [25]. Accordingly, total serum IgG4 concentrations are higher among asymptomatic atopic patients [18] (Figure 1). In patients with IgG4-RD, the positive correlation between serum IgG4 concentrations and IgG4 responses to multiple food and animal antigens could indicate polyclonal expansion and differentiation of pre-existing B cells in IgG4-related disease [26].
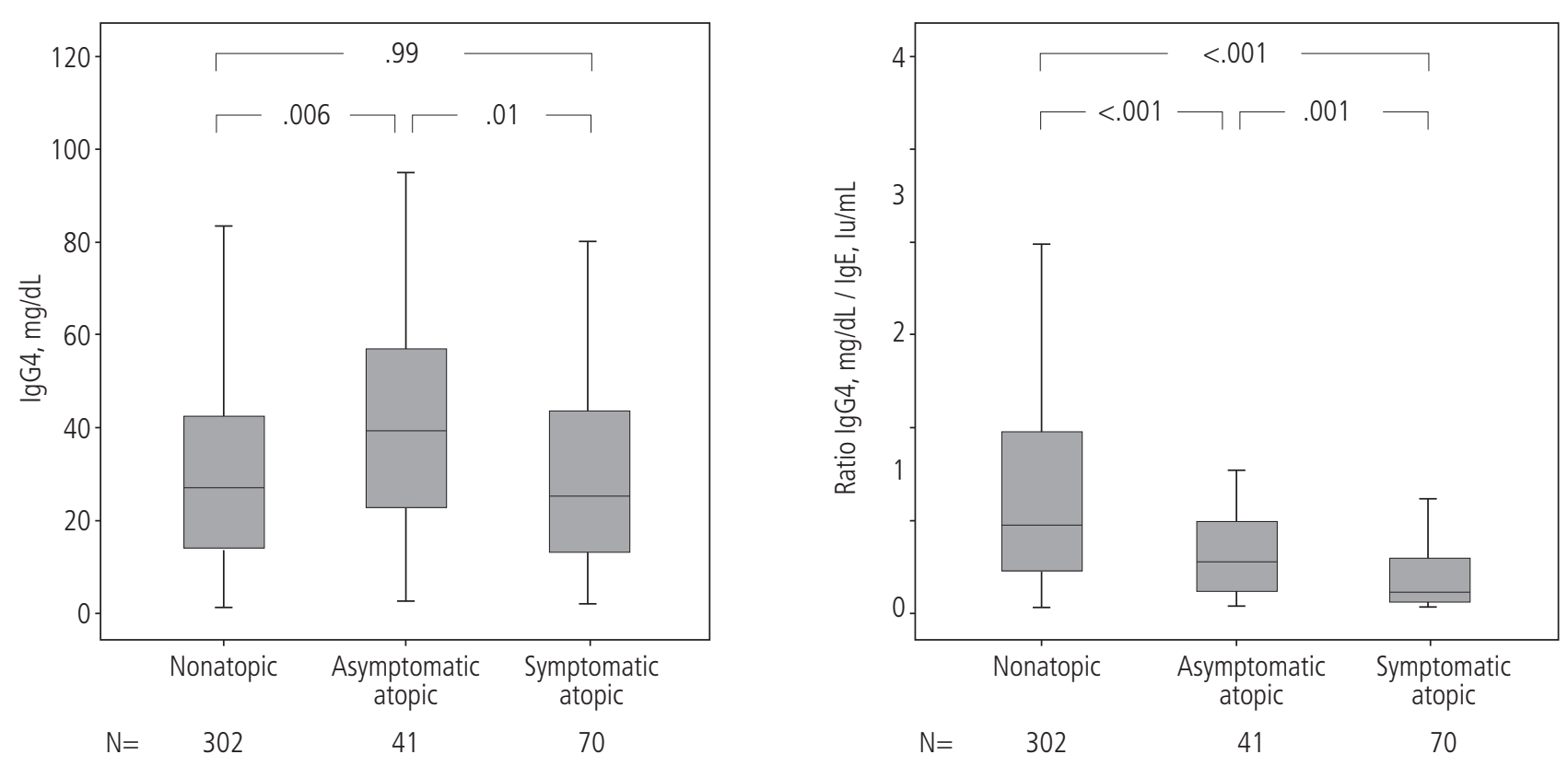

Figure 1. Serum concentrations of $\lg G 4$ and ratio of $\lg G 4$ to total $\lg$ in a general adult population sample stratified by atopy and respiratory symptoms [18] Participants were randomly selected from a municipality in Northern Spain. Atopy was assessed by positivity to any of a panel of common aeroallergens in the area. Respiratory (nasal and/or bronchial) symptoms were assessed using a questionnaire. Serum concentrations of total lgG4 tended to be higher in asymptomatic atopic persons than in nonatopic persons and in symptomatic atopic persons (left panel). As a consequence (and given the highest levels of total $\lg$ E in symptomatic atopic individuals), the highest ratio of $\lg G 4$ to total $\lg E$ tends to be highest in nonatopic individuals and in asymptomatic atopic individuals (right panel). 


\section{Etiology and Pathophysiology of IgG4-Related Disease}

The pathogenesis of IgG4-RD is poorly understood. Elevated serum concentrations of IgG4 and tissue infiltration by IgG4-expressing cells constitute the hallmark of IgG4$\mathrm{RD}$ [1]; yet, these findings are not specific to IgG4-RD, because they can be found in many diseases, mainly in inflammatory conditions and malignancies $[1,10,11,27-30]$. In any case, the presence of a dense lymphoplasmacytic infiltrate, storiformtype fibrosis, and obliterative phlebitis are specific for IgG4$\mathrm{RD}[10]$.

Numerous self-antigens have been reported as potential autoantigens responsible for the pathogenesis of IgG4-RD [31]. However, it is unclear whether IgG4 antibodies are pathogenic in IgG4-RD or merely represent a regulatory response to another primary autoimmune or allergic process [1,19,31-35]. In an experimental animal model, subcutaneous injection of IgG1 or IgG4 from patients with IgG4-RD resulted in pancreatic and salivary gland injuries. Interestingly, $\operatorname{IgG} 1$ induced more destructive changes than IgG4 [36], although the relevance of $\operatorname{IgG} 1$ in the disease is uncertain.

The fact that IgG4-RD involves organs with exocrine functions and immune barriers suggests a possible role for infectious agents (eg, Helicobacter pylori, gram-negative bacteria, and Mycobacterium tuberculosis) [37], antigens, and even occupational exposure [38] as triggers of the disease. Besides, the presence of serum antinuclear antibodies, immune complex deposition, serum IgE elevation, and peripheral blood eosinophilia in patients with IgG4-RD [1,27,39] supports $\mathrm{T}_{\mathrm{H}} 2$ overactivity. However, accurate analysis of circulating $T$ cells in IgG4-RD for $T_{H} 1 / T_{H} 2 /$ Treg polarization has led to conflicting results, since only patients with a history of atopy show expansion of $\mathrm{T}_{\mathrm{H}} 2$ memory $\mathrm{CD}^{+} \mathrm{T}$ cells $[33,34]$. $\mathrm{CD}^{+}$ cytotoxic T lymphocytes (CTLs) with cytolytic functions that express SLAMF7 on their surface are the most abundant $\mathrm{CD}^{+} \mathrm{T}$ type in this disease [40]. The cytotoxic molecules secreted by these $\mathrm{CD} 4^{+} \mathrm{CTL}$ cells such as perforin, granzyme $\mathrm{A} / \mathrm{B}$, granulysin and profibrotic cytokines (IL- $1 \beta$, IFN- $\gamma$, and TGF- $\beta 1$ ) are responsible for inflammation and later fibrosis in tissues [40,41]. Moreover, the involvement of B cells is strongly suggested by the clinical response of patients treated with rituximab [42,43], a monoclonal antibody targeting CD20. The fact that $\mathrm{CD}^{+} \mathrm{SLAMF}^{+}$CTLs do not express CD20 but are decreased by rituximab indicates that they could be continuously activated by B cells and plasmablasts through repeated antigen presentation [42].

Tertiary lymphoid organs are formed at affected tissue sites [1], promoted by IL-21, a cytokine produced by $\mathrm{T}_{\mathrm{H}} 2$ cells and $\mathrm{T}$ follicular helper (Tfh) cells $[44,45]$. Increased production of IL-10 and TGF $\beta-1$ by Tfh and Treg cells promotes IgG4 synthesis and fibrosis [46,47]. Massive infiltration by inflammatory cells with the formation of lymphoid follicles leads to enlargement of the affected organs and results in their dysfunction [48].

IgG4-RD has been also related to genetic factors. Several studies report an association between human leukocyte antigen (HLA) genes and non-HLA genes and incidence or relapse of IgG4-RD $[49,50]$. Interestingly, reduced expression of innate immunity-related genes may participate in the pathogenesis of IgG4-RD [51].

Finally, a subset of cases of IgG4-RD may be associated with a previous malignancy [52]. Potential explanations include shared risk factors for both IgG4-RD and cancer, cancer-induced autoantigen expression leading to IgG4-RD, and an increased risk of IgG4-RD resulting from cancer treatment [52].

\section{Clinical Manifestations of IgG4-Related Disease}

IgG4-RD is often a subacute condition that can affect 1 or more organs to produce inflammatory masses or diffuse enlargement $[1,27,53,54]$; therefore, it usually manifests as tumors or swelling with variable periods of remission and reactivation. More than half of patients have 2 or more organs affected [55]. Accordingly, clinical expression of IgG4-RD is quite variable, depending on the main affected organ (Table 1). The disease may be asymptomatic or produce constitutional syndrome with no fever $[1,27,54]$, especially in cases of extensive multiorgan involvement. IgG4-RD has a strong predilection for certain organs [12].

The pancreas is the most commonly affected organ in IgG4-RD [7]. Around 4\%-6\% of cases of chronic pancreatitis are associated with the disease [56]. IgG4-RD could be misdiagnosed as pancreatic cancer presenting as a pancreatic mass with painless obstructive jaundice [57] (Figure 2). Up to $70 \%$ of patients with pancreatic involvement have sclerosing cholangitis, which manifests clinically as obstructive jaundice, weight loss, and mild abdominal discomfort [53].

Salivary or lachrymal gland involvement is common in IgG4-RD [7,55]. Subacute enlargement of submandibular and/or parotid glands, sometimes with sicca symptoms [7]

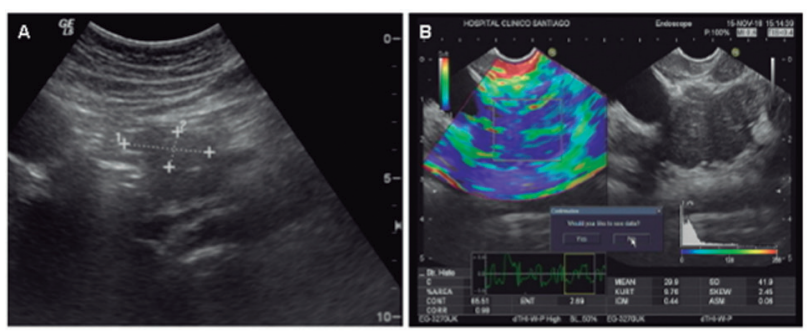

Figure 2. Ultrasound images corresponding to a 15-year-old male presenting with extrahepatic obstructive jaundice. He had been diagnosed with rhinoconjunctivitis and bronchial asthma with IgE-mediated sensitization to pollens and mites. A, Standard abdominal ultrasound showing a $3 \times 2 \mathrm{~cm}$ hypoechoic mass in the head of the pancreas. $B_{\text {, }}$ Endoscopic ultrasound confirming the heterogeneous pancreatic mass; elastography for evaluation of stiffness reveals a hard (predominantly blue) pattern with a strain ratio $>10$. Serum IgG4 was $147 \mathrm{mg} / \mathrm{dL}$, and serum IgE was $59 \mathrm{U} / \mathrm{L}$. Autoimmune pancreatitis in this case could be classified as focal according to the criteria of Vlachou et al [58]. The pancreatic lesion and obstructive jaundice gradually resolved with corticosteroids.

Original images from Complejo Hospitalario Universitario de Santiago, Santiago de Compostela, Spain. Written informed consent was provided by the patient for their publication in medical journals. 
(previously known as Küttner tumor [4]), is frequent. Lacrimal gland involvement often produces dacryoadenitis, with painless swelling of the area and prominence of the affected eye [59]. Involvement of both salivary and lacrimal glands is known as Mikulicz syndrome $[4,60]$. The orbital fat, extraocular muscles, and trigeminal nerve [60] can also be affected, and patients may present with eyelid swelling or mass effect [60]. In fact, the most frequent manifestation of IgG4-RD in children (44\%) is the orbital variant of the disease [14].

Retroperitoneal fibrosis is one of the most frequent forms of IgG4-RD in some Western countries, such as Spain $[55,61]$, and a high percentage of idiopathic retroperitoneal fibrosis is likely to be IgG4-RD $[62,63]$. Fibrosis typically encompasses
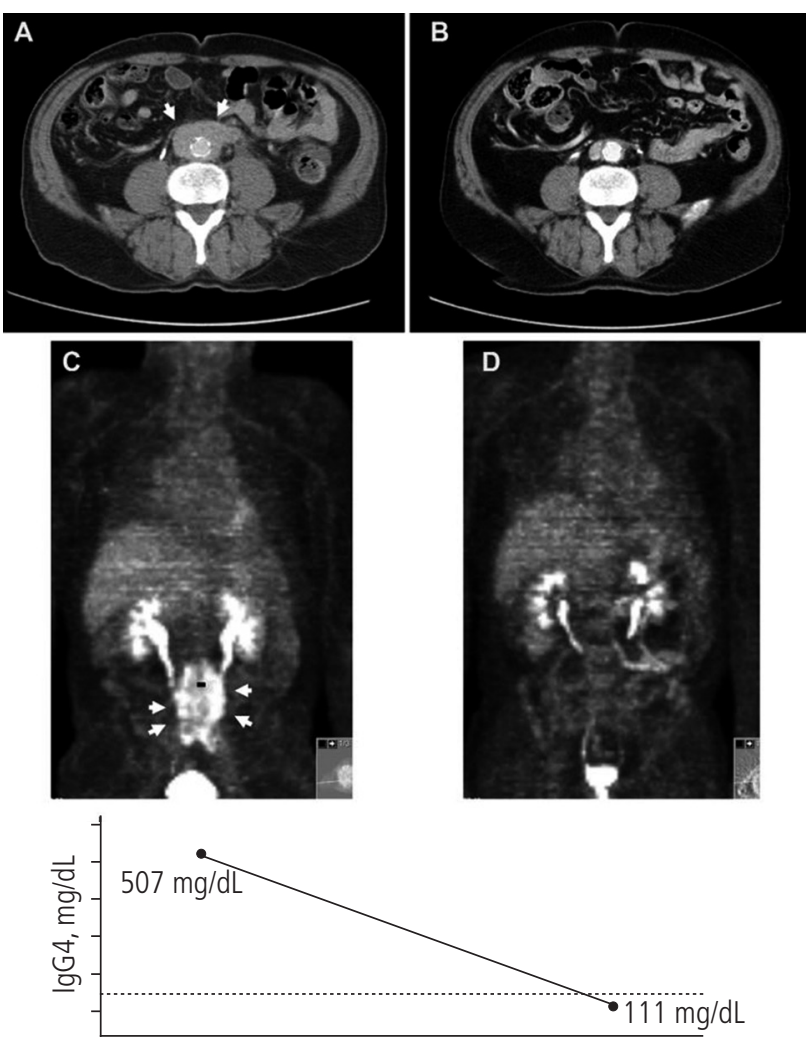

Baseline

Month 4

Figure 3. Clinical images corresponding to a 78-year-old man presenting with signs of bilateral obstructive uropathy. A double-J stent was placed in both urinary tracts to resolve obstruction. A, Computed tomography (CT) scan showing a mass surrounding the aorta (arrows) and involving both ureters. B, Four months after corticosteroid therapy (prednisone, $1 \mathrm{mg} / \mathrm{kg}$ in tapering doses) the periaortic mass had nearly disappeared in the CT scan. C, Positron emission tomography (PET) with fluorodeoxyglucose showing an area of hypermetabolism (arrows) that corresponds to the perivascular inflammatory disease. D, Four months after corticosteroid therapy (prednisone, $1 \mathrm{mg} / \mathrm{kg}$ in tapering doses) the area of hypermetabolism had resolved in the PET. Bottom: Serum IgG4 concentrations at baseline and at the fourth month of therapy. The dotted line represents the threshold criterion for lgG4-related disease. Four years after the initial diagnosis, the patient is asymptomatic under a minimal corticosteroid dose. Serum IgG4 increased again (to a lesser extent), although recurrence was not observed on the CT scan.

Original images from Complejo Hospitalario Universitario de Santiago, Santiago de Compostela, Spain. Written informed consent was provided by the patient for their publication in medical journals. the aorta, iliac arteries, and ureters, sometimes causing obstructive renal failure $[7,62,63]$ (Figure 3). Sclerosing mesenteritis may also be recorded [7]. Periaortitis/periarteritis is common $[62,64]$, especially at the infrarenal segment of the abdominal aorta, and is reported to be present in 10\%-30\% of overall IgG4-related disease [64].

IgG4-RD affecting the thorax may induce cough, dyspnea, chest pain, pleurisy, and bloody sputum/hemoptysis $[65,66]$ (Figure 4). It can mimic pneumonia, or present with interstitial pneumonitis, bronchial thickening, bronchiectasis, interstitial involvement (ground-glass opacities, honeycombing pattern), nodules, lung tumors, and pleural thickening or tumor $[53,65]$.

The most common clinical presentation of IgG4-RD in the kidney is tubulointerstitial nephritis [67]. IgG4-related membranous nephropathy or glomerulonephritis may occur, although these conditions are much more infrequent [68].
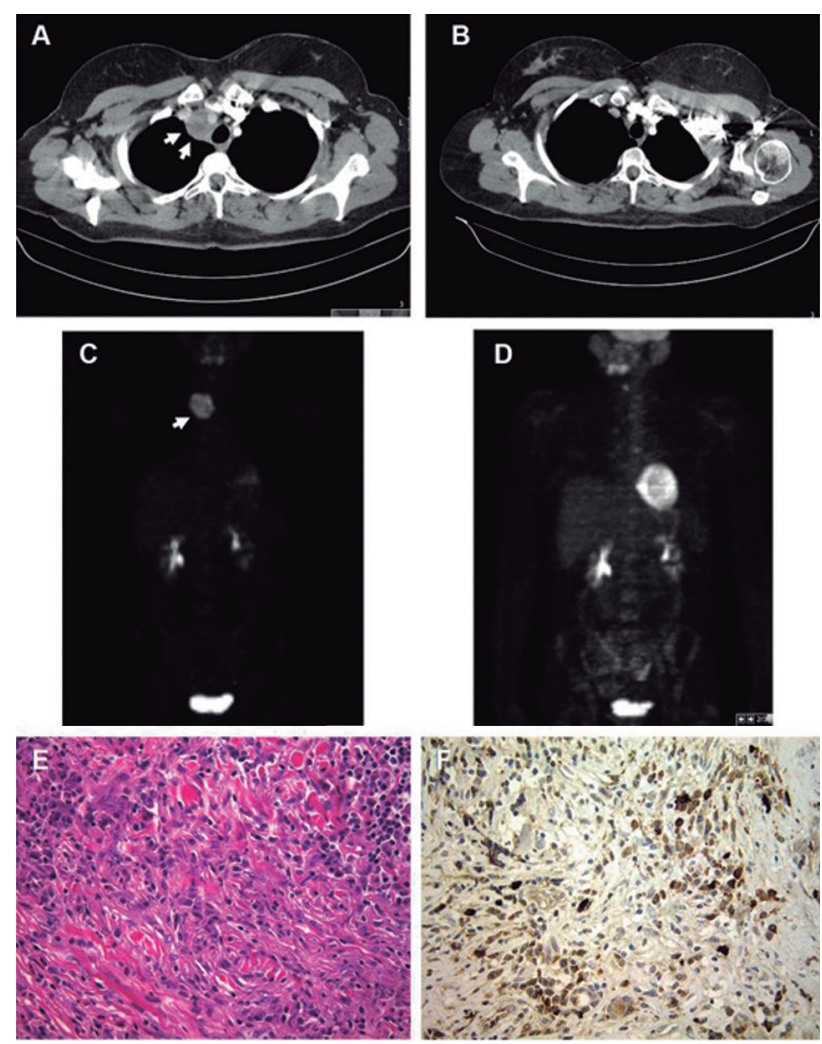

Figure 4. Clinical images corresponding to a 36-year-old woman presenting with right Horner syndrome (miosis and palpebral ptosis) and cough. A, Computed tomography (CT) scan showing a cervicothoracic mass (arrows). B, Three months after corticosteroid therapy (prednisone, $30 \mathrm{mg} / \mathrm{d}$ in tapering doses), the mass had nearly disappeared in the CT scan. C, Positron emission tomography (PET) with fluorodeoxyglucose showing an area of hypermetabolism (arrows) that corresponds to the cervicothoracic mass. D, Three months after corticosteroid therapy (prednisone, $30 \mathrm{mg} / \mathrm{d}$ in tapering doses), the area of hypermetabolism had resolved in the PET. Bottom: Biopsy of the cervicothoracic mass. E, Hematoxylin-eosin staining showing extensive fibrosis and moderated infiltration by mononuclear cells. F, Immunohistochemistry showing lgG4-positivity of lymphoid cells. Five years after the initial diagnosis, the patient is asymptomatic with no therapy and no evidence of recurrence.

Original images from Complejo Hospitalario Universitario de Santiago, Santiago de Compostela, Spain. Written informed consent was provided by the patient for their publication in medical journals. 
Table 2. Clinical Phenotype Groups Proposed by the lgG4-RD Classification Criteria Committee of the American College of Rheumatology/European League Against Rheumatism [16]

\begin{tabular}{ll} 
Group & Affected Organs \\
\hline 1 & Pancreato-hepato-biliary disease \\
2 & Retroperitoneal fibrosis and/or aortitis \\
3 & Head and neck-limited disease \\
4 & Mikulicz syndrome with systemic involvement \\
\hline
\end{tabular}

Lymphadenopathy has been reported in $26 \%-49 \%$ of patients with systemic presentations of IgG4-RD [7,69]. Enlarged lymph nodes can be located in the same regions where IgG4-related extranodal disease is present, or in different regions and may also be the initial or only manifestation [70].

Finally, IgG4-RD may affect virtually any organ, including the thyroid (Riedel thyroiditis [71] and the fibrous variant of Hashimoto thyroiditis [72]), meninges [73], hypophysis [74], nose and sinuses [75], esophagus [76], mediastinum [77], pericardium [78], breast [79], prostate [80], skin [81], and others (Table 1).

The ACR/EULAR IgG4-RD Classification Criteria Committee has proposed 4 clinical phenotype groups [16] (Table 2).

\section{Laboratory Features of IgG4-Related Disease}

\section{Routine Laboratory Determinations}

Routine laboratory findings are not specific for IgG4RD. One third of patients with IgG4-RD have blood eosinophilia [27,32,82-85], positive antinuclear antibodies [27], and low complement levels [27]. Hypocomplementemia, with particularly low levels of serum $\mathrm{C} 3$ and $\mathrm{C} 4$ complement fractions, is more common in patients with IgG4-related kidney disease [86]. Serum acute phase reactants such as C-reactive protein and positive rheumatoid factor can be detected in $20 \%$ of patients [27]. Hypergammaglobulinemia due to increased total $\mathrm{IgG}$ is present in approximately $60 \%$ of patients [27], particularly in those with more extensive disease, and total serum IgE in approximately $30 \%-60 \%$ of patients with IgG4RD $[27,32,82,83]$, or even more than $60 \%[84,85,87,88]$. Baseline elevations in total serum IgG4, total serum IgE, and eosinophil count are important predictors of relapse $[89,90]$.

\section{Serum IgG4 Concentrations}

Serum IgG4 concentrations are useful for diagnosis, prognosis, and monitoring of patients with IgG4-RD [89-91] (Figure 3). Most patients with IgG4-RD display serum IgG4 concentrations higher than $135 \mathrm{mg} / \mathrm{dL}$, which is the generally accepted cut-off for diagnosis $[3,92]$. However, IgG4 measurements have some drawbacks for diagnosis. First, serum levels can vary depending on the method used for determination [93]. According to the manufacturer's instructions of 2 commonly used commercial kits, normal reference IgG4 concentrations may be $3.9-86.4 \mathrm{mg} / \mathrm{dL}$ (5-95 percentile range, The Binding Site) or $3.0-201 \mathrm{mg} / \mathrm{dL}$ (2.5-97.5 percentile range, Siemens Diagnostic Solutions). Second, IgG4 concentrations may be falsely underestimated owing to the prozone effect that can occur with some nephelometry assays in the setting of high antigen excess [94]. Third, serum concentrations of IgG4 depend on demographics: they are higher in males than in females, decrease with age in adults [18], and are probably higher in Black and

Table 3. Clinical Entities With Potentially Increased Serum IgG4 Concentrations

\begin{tabular}{|c|c|}
\hline Clinical Entity & $\begin{array}{c}\text { Patients With } \\
\text { Increased Serum } \\
\text { IgG4 }\end{array}$ \\
\hline $\begin{array}{l}\text { Eosinophilic granulomatosis with } \\
\text { polyangiitis }\end{array}$ & $70-71 \%[27,29]$ \\
\hline Castleman disease & $44 \%[27,29]$ \\
\hline Allergic disease & $42 \%[28]$ \\
\hline Ankylosing spondylitis/psoriatic arthritis & $40 \%[28]$ \\
\hline Gastrointestinal malignancy & $39 \%$ [28] \\
\hline Lymphoma & $34 \%[28]$ \\
\hline Interstitial lung disease & $33 \%[27]$ \\
\hline Interstitial pneumonia & $33 \%[29]$ \\
\hline Rheumatoid arthritis & $15-33 \%[27-29]$ \\
\hline SAPHO syndrome & $23 \%[101]$ \\
\hline Biliary tract cancer/cholangiocarcinoma & $6-21 \%[27-29]$ \\
\hline Asthma & $14-20 \%[27,29]$ \\
\hline Non-IgG4-related pancreatitis & $19 \%[28]$ \\
\hline Sjögren syndrome & $5-19 \%[27-29]$ \\
\hline Pancreatic cancer & $5-18 \%[27-29]$ \\
\hline Malignancy (various) & $16 \%[28]$ \\
\hline Idiopathic neuropathy & $15 \%[29]$ \\
\hline Sarcoid-like disease & $14 \%[29]$ \\
\hline Systemic lupus erythematosus & $8-14 \%[27-29]$ \\
\hline Hypereosinophilic syndrome & $13 \%[27,29]$ \\
\hline Cholangitis & $13 \%[28]$ \\
\hline Microscopic polyangiitis & $12 \%[29]$ \\
\hline Behçet disease & $10 \%[27]$ \\
\hline Chronic pancreatitis & $4-10 \%[27,29]$ \\
\hline Acute pancreatitis & $9 \%[29]$ \\
\hline Liver cirrhosis & $9 \%[27,29]$ \\
\hline Autoimmune hepatitis & $8 \%[29]$ \\
\hline Systemic sclerosis & $7 \%[27,29]$ \\
\hline Intraductal papillary mucinous neoplasm & $7 \%[29]$ \\
\hline Ulcerative colitis & $6 \%[29]$ \\
\hline Chronic hepatitis & $5 \%[27,29]$ \\
\hline Benign pancreatic tumor & $5 \%[29]$ \\
\hline Other pancreatic abnormalities & $4 \%[29]$ \\
\hline Sarcoidosis & $4 \%[29]$ \\
\hline Healthy controls & $1 \%[18,27,29]$ \\
\hline
\end{tabular}


more especially, Asian than White individuals [95]. Fourth, the diagnostic accuracy of serum IgG4 for IgG4-RD depends on how patients have been identified in each cohort [16,27]. When cases are detected based on biopsy findings, sensitivity drops to $50 \%$ [86]. When cases are detected based on elevated serum IgG4 levels, sensitivity is obviously higher [96]. Finally, the serum IgG4 cutoff value was established by focusing on patients with specific subsets of IgG4-RD, particularly with type 1 autoimmune pancreatitis [3]. The optimum cut-off value probably depends on the clinical presentation and the affected organ. Asian studies show optimal cut-off values of serum IgG4 for the diagnosis of IgG4-RD higher than $135 \mathrm{mg} / \mathrm{dL}$, namely, $248 \mathrm{mg} / \mathrm{dL}$, with sensitivity and specificity of $77.6 \%$ and $92.8 \%$, respectively [28], and $210 \mathrm{mg} / \mathrm{dL}$, with sensitivity and specificity of $94.7 \%$ and $91.6 \%$, respectively [97].

High concentrations of IgG4 are correlated with a high degree of swelling in affected organs, multiorgan involvement, elevated acute phase reactants, symptoms, and Asian race [16,98-100]. High concentrations of IgG4 in patients with active disease are also correlated with older age, higher IgG4-RD Responder Index score, more organs involved, lower complement levels, higher absolute eosinophil counts, and higher IgE levels [86]. Regarding specificity, IgG4 may also be increased in patients with other diseases (Table 3), although higher levels ( $>2$-fold) have been useful for distinguishing IgG4-RD from cancer [102]. Some studies have investigated the diagnostic value of the IgG4/total IgG ratio for the diagnosis of IgG4-RD, and diagnostic thresholds higher than $8 \%$ or $11.4 \%$ have been proposed [96,97]. Nevertheless, the sensitivity and specificity of this criterion do not substantially improve the sensitivity and specificity of serum IgG4 concentrations [96,97].

\section{Plasmablasts and Other Biomarkers}

Flow cytometry analysis of peripheral blood is used to measure circulating $\mathrm{CD} 19^{+} \mathrm{CD} 27^{+} \mathrm{CD} 20^{-} \mathrm{CD} 38^{\text {hi }}$ plasmablasts, largely IgG4+ [103], which could correlate better with IgG4RD activity than serum IgG4 levels [99]. These plasmablasts are especially relevant in the initial phases of the disease and during outbreaks $[99,103]$. They could serve as a marker of activity, since elevation of blood plasmablasts coincides with outbreaks of the disease and drops drastically with effective treatment [103]. Therefore, serial measurements have been proposed as a possible longitudinal marker for monitoring activity in patients with IgG4-RD [27,86,99,104]. A plasmablast count of $900 / \mathrm{mL}$ is reported to have a sensitivity value of $95 \%$, a specificity of $82 \%$, a positive predictive value of $86 \%$, and a negative predictive value of $97 \%$ [99]. Other promising tools for the diagnosis and monitoring of IgG4-RD include dominant IgG4+ B-cell receptor clones [105], the blood IgG4/IgG RNA ratio measured by quantitative polymerase chain reaction [105], and circulating PD1+ Tfh2 cells [106].

\section{Imaging Features of IgG4-Related Disease}

Incidental findings on radiologic studies performed for different reasons are quite common in IgG4-RD [11].
Nonspecific tumors and enlarged organs are frequent, and location depends on the organ affected. The imaging features are generally nonspecific and do not enable reliable distinctions between IgG4-related disease and cancer [1]. On computed tomography (CT) scans, the lesions usually display homogeneous attenuation and enlargement of the organ; on magnetic resonance imaging (MRI), they display relatively low signal intensity on T2-weighted images owing to fibrosis [107].

\section{Pancreas}

Imaging reveals focal, multifocal, or diffuse pancreatic enlargement [58]. CT scan and MRI can show a diffusely enlarged pancreas with loss of lobular contours and loss of surface clefts surrounded by a sausage-shaped peripancreatic halo [58]. The focal pattern usually affects the pancreatic head and mimics pancreatic adenocarcinoma [58] (Figure 2). Intra- and extrahepatic bile ducts are commonly affected, leading to prestenotic expansion [108]. While the condition can be confused with primary sclerosing cholangitis, the latter progresses more slowly, with involvement of multifocal short sections and a "pruned tree" appearance [108].

\section{Lungs}

Four different subtypes can be identified, as follows: (a) solid nodular type, ie, a solitary nodular or mass lesion (Figure 4); (b) multiple round-shaped ground-glass opacity; (c) alveolar interstitial type showing honeycombing, bronchiectasis, and diffuse ground-glass opacities; and $(d)$ bronchovascular type showing thickening of bronchovascular bundles and interlobular septa [66].

\section{Kidneys}

Five different patterns have been identified, with bilateral round or wedge-shaped peripheral cortical lesions being the most common, although other possible imaging findings include diffuse patchy involvement, a rim of soft tissue around the kidney, bilateral nodules in the renal sinuses, and diffuse wall thickening in the renal pelvis [107,109].

\section{Retroperitoneum}

Fibrosis, which frequently surrounds the abdominal aorta and iliac arteries (typically in the vicinity of atherosclerotic plaques) over the anterior surface of the fourth and fifth lumbar vertebrae, may result in entrapment and obstruction of retroperitoneal structures, particularly the ureters $[62,63]$ (Figure 3). In sclerosing mesenteritis, the preservation of fat around the mesenteric vessels helps distinguish neoplastic processes. This characteristic is known as the fat ring sign [110].

Although ultrasound, CT scan, and MRI are helpful techniques for evaluation of IgG4-RD, positron emission tomography (PET; and PET/CT) plays a major role in the initial diagnosis and follow-up, enabling disease activity to be monitored after treatment and during longterm surveillance $[111,112]$ (Figures 3 and 4). Functional imaging with 18-fluorodeoxyglucose PET is highly effective in establishing the extent of the disease and should be 
Table 4. Consensus Statement on the Pathology of IgG4-Related Disease [10]

\begin{tabular}{lc}
\hline & Criteria \\
\hline Histopathological features & Quantitative assessment of IgG4 stain \\
\hline Three major histopathological features: & Infiltrates of IgG4+ plasma cells/hpf \\
- Dense lymphoplasmacytic infiltrate & $->10$ meninges, liver (b), bile duct (b), pancreas (b), kidney (b) \\
- Fibrosis, arranged at least focally in a storiform pattern & $->20$ lung (b) \\
- Obliterative phlebitis & $->30$ kidney (sp), retroperitoneum \\
& $->50$ lung (sp), pleura, aorta, liver (sp), bile duct (sp), \\
Other histopathological features: & pancreas (sp), lymph node \\
- Phlebitis without obliteration of the lumen & $->100$ lacrimal gland, salivary gland \\
- Increased numbers of eosinophils & $->200$ skin
\end{tabular}

$\mathrm{IgG} 4+/ \mathrm{IgG}+$ cell ratio $>40 \%{ }^{\mathrm{b}}$

Proposed diagnostic terminology for IgG4-related disease

$\begin{array}{ll}\text { Histologically highly suggestive of IgG4-related disease } & 2 \text { of the } 3 \text { major histopathological features } \\ & +\end{array} \quad \begin{array}{ll}\text { IgG4 } 4+\text { plasma cells }>10-200 \text { and ratio }>40 \% 0^{\mathrm{b}}\end{array}$

Histologically probable IgG4-related disease

These cases either lack the full histological spectrum associated with IgG4-related disease or the immunohistochemical profile of IgG4-related disease. This category is also applied to organs where the concept of IgG4-related disease is not completely established

\begin{abstract}
Insufficient histopathological evidence of IgG4-related disease Cases outside the other 2 categories described
alt should be noted that there are no pathognomonic signs and there are no universally accepted diagnostic criteria for the entire spectrum of IgG4related disease. Correlation with clinical data is of foremost importance [10]. In the lacrimal gland, both storiform fibrosis and obliterative phlebitis may be absent [10]. Thus, 1 histological feature compatible with IgG4-related disease might suffice for the diagnosis of dacryoadenitis [10]. Additional exceptions are lymph nodes, the lung, and the oral mucosa [10].

blt has been proposed that a cell ratio $>50 \%$ should be the minimum criterion in aortic specimens [10].

'Applicable to the following specimens: lacrimal gland, salivary gland, lung (sp), pleura, aorta, liver (sp), bile duct (sp), pancreas, kidney, retroperitoneum. Abbreviations: b, biopsy; hpf, high-power field $(400 \times)$; sp, surgical specimen.
\end{abstract}

considered a baseline evaluation in all patients at the time of initial diagnosis [111]. PET/CT has a sensitivity of $86 \%$ and specificity of $66 \%$ for diagnosing IgG4-RD [113].

\section{Histopathological Features of IgG4-Related Disease}

The 3 major histopathological features associated with IgG4-related disease are $(a)$ a dense lymphoplasmacytic infiltrate, $(b)$ a storiform pattern of fibrosis, and $(c)$ obliterative phlebitis [10] (Table 4). Tissue counts of IgG4-positive cells and $\mathrm{IgG} 4+/ \mathrm{IgG}+$ ratios are secondary in importance [10]. The criteria used to consider the presence of these plasma cells as diagnostic vary from one organ to another (Table 4). Given the patchy distribution of IgG4-positive cells, counting areas of intense IgG4 focus ("hot spots") might be more representative [10]. For that reason, 3 high-power fields should be analyzed, and the average number of IgG4-positive plasma cells and the IgG4-to-IgG ratio should be calculated [10].

\section{Diagnosis of IgG4-Related Disease}

The most accurate assessment of IgG4-RD is based on a full clinical history, physical examination, selected laboratory investigations, and appropriate imaging studies [11]. It is accepted that confirmation of IgG4-RD needs tissue biopsy for exclusion of malignancy and other entities that can mimic IgG4-RD [11].

Several scientific societies have proposed diagnostic criteria for specific organ disease, particularly for autoimmune pancreatitis, sclerosing cholangitis, Mikulicz disease, IgG4related tubulointerstitial nephritis, kidney disease, ophthalmic disease, respiratory disease, and periaortic/periarterial and retroperitoneal disease. However, comprehensive diagnostic criteria for IgG4-RD were proposed by Umehara et al [92] (Table 5) and validated in a cohort of 48 cases with IgG4-RD as the final diagnosis and 5 cases in which IgG4-RD was ruled out, with high sensitivity and specificity $(97.9 \%$ and $80.0 \%$, respectively) [114].

The 2019 ACR/EULAR Classification Criteria for IgG4Related Disease [12] were designed to identify homogeneous groups of patients for inclusion in research studies, although they are very useful for diagnosis of IgG4-RD in patients with typical organ involvement. Neither biopsy nor elevated serum IgG4 level is indispensable [12]. A case meets the classification criteria for IgG4-RD if at least 1 of the 2 entry criteria are met, namely, (1) characteristic clinical or radiologic involvement of a typical organ (pachymeninges, lacrimal glands, orbits, major salivary glands, thyroid, lung, aorta, bile ducts, pancreas, kidney, and retroperitoneum) or (2) pathologic evidence of an 
Table 5. Comprehensive Diagnostic Criteria for lgG4-Related Disease [92]

\begin{tabular}{|c|c|}
\hline \multicolumn{2}{|l|}{ Diagnostic Criteria } \\
\hline Clinical & $\begin{array}{l}\text { Diffuse/localized swelling or masses } \\
\text { in single or multiple organs }\end{array}$ \\
\hline Hematological & $\begin{array}{l}\text { Elevated serum IgG4 concentrations } \\
(\geq 135 \mathrm{mg} / \mathrm{dL})\end{array}$ \\
\hline Histopathological & $\begin{array}{l}\text { - Marked lymphocyte and plasmacyte } \\
\text { infiltration and fibrosis } \\
\text { - Infiltration of IgG4+ plasma cells: } \\
\text { ratio of IgG4+/IgG }+ \text { cells }>40 \% \text { and } \\
>10 \text { IgG4+ plasma cells } / \text { hpf }\end{array}$ \\
\hline \multicolumn{2}{|c|}{ Proposed Diagnostic Terminology for IgG4-Related Disease } \\
\hline Definite & $\begin{array}{l}\text { Clinical + hematological + } \\
\text { histopathological }\end{array}$ \\
\hline Probable & Clinical + histopathological \\
\hline Possible & Clinical + hematological \\
\hline
\end{tabular}

The table summarizes the article Comprehensive diagnostic criteria for IgG4-related disease (IgG4-RD), 2011 [92]. The comprehensive diagnostic criteria comprise the minimum consensus necessary to aid general practitioners and other nonspecialist physicians in the clinical diagnosis of IgG4-RD [92]. In patients without a definitive diagnosis of IgG4-RD according to the comprehensive diagnostic criteria, organ-specific criteria for lgG4-RD should be applied [92]. The clinicalpathological correlation is of the utmost importance, including the differentiation between malignant tumors of each organ and diseases that may resemble lgG4-RD (eg, Sjögren syndrome, primary sclerosing cholangitis, Castleman disease, secondary retroperitoneal fibrosis, Wegener granulomatosis, sarcoidosis, and Churg-Strauss syndrome) [92]. Abbreviation: hpf, high-power field $(\times 400)$.

inflammatory process accompanied by a lymphoplasmacytic infiltrate of uncertain etiology in one of these same organs. In addition, no exclusion criteria can be present, and the total points for the inclusion criteria must be $\geq 20$ [12]. The criteria were validated in 2 cohorts of 908 and 485 patients with IgG4-RD or mimickers. The sensitivity and specificity were $85.5 \%$ and $99.2 \%$ in the first cohort and $82 \%$ and $97.8 \%$ in the second cohort [12].

\section{Differential Diagnosis of IgG4-Related Disease}

The main differential diagnosis for IgG4-RD is with cancer, particularly when IgG4-RD presents as a single inflammatory tumor. Multifocal IgG4-RD may also mimic a metastatic neoplasm. Multiple types of cancer and other diseases (eg, eosinophilic granulomatosis with polyangiitis, Castleman disease, allergic disease, rheumatoid arthritis, systemic lupus erythematosus, interstitial lung disease, and Sjögren syndrome) may exhibit high serum IgG4 levels [27-29,101] (Table 3) and/or increased numbers of IgG4+ plasma cells in tissue [11,27,29,30] (Table 6).

However, the constellation of key histological features (dense lymphoplasmacytic infiltrate, storiform pattern of fibrosis, and obliterative phlebitis) with an $\mathrm{IgG} 4+/ \mathrm{IgG}+$ cell ratio $>40 \%$ is not frequently present in entities other than IgG4$\mathrm{RD}$ [10]. Diagnosis is based on a proper clinicopathologic correlation performed by clinicians and pathologists after reviewing and discussing the patient's clinical features and histopathology findings [11].

\section{Treatment and Management of lgG4-Related Disease}

Treatment is recommended in most cases, despite the possible spontaneous remission, because of potential irreversible damage to some organs [11]. Systemic corticosteroids are the treatment of choice for inducing remission [11]. The dose should be adjusted to body weight and depends on the location and severity of the disease [11]. The most common schedule consists of prednisone (or equivalent) at an initial dose of 0.4 to 0.7 or even $1 \mathrm{mg} / \mathrm{kg} / \mathrm{d}$ in some cases; $0.6 \mathrm{mg} / \mathrm{kg} / \mathrm{d}$ of prednisolone improves disease course in more than $90 \%$ of patients [115]. In patients with acute kidney failure, imminent threat to vision, substantial neurological risk from an active IgG4-RD lesion, or other dangerous situations, a pulse of methylprednisolone therapy in doses ranging from $100-1000 \mathrm{mg} / \mathrm{d}$ for 3 days may be recommended [116]. Endoscopy or surgery is necessary in some cases. However, surgery alone does not seem to be a viable treatment for IgG4-RD [117].

Maintenance therapy often includes corticosteroids for 3-6 months with tapering doses after 2-4 weeks [11]. Prolonged maintenance therapy with oral prednisone at a dose of 2.5$5 \mathrm{mg} / \mathrm{d}$ may be considered if there is a substantial risk of relapse [11]. A fast reduction $(>0.4 \mathrm{mg} / \mathrm{d})$ in the early treatment of IgG4-RD was associated with increased risk of relapse [118].

Inconsistent results have been reported for some immunosuppressive agents. Yunyun et al [119] performed a randomized clinical trial to investigate the efficacy of prednisone/prednisolone $0.6-0.8 \mathrm{mg} / \mathrm{kg} / \mathrm{d}$ for $1 \mathrm{month}$ and tapered gradually compared to the same corticosteroid pattern combined with mycophenolate mofetil $1-1.5 \mathrm{~g} / \mathrm{d}$ for 6 months and then decreased to $0.5-1.0 \mathrm{~g} / \mathrm{d}$. The cumulative relapse rate after 1 year of therapy was lower in the combination group ( $21 \%$ vs $40 \%, P=.059)$, with no differences in adverse reactions [119]. A nonrandomized trial evaluated the efficacy of prednisone $0.5-1.0 \mathrm{mg} / \mathrm{kg} / \mathrm{d}$ for 1 month, decreased $5 \mathrm{mg}$ every 2 weeks, maintained at 5-10 mg/d for 12 months, compared with the same prednisone pattern, and cyclophosphamide 50$100 \mathrm{mg} / \mathrm{d}$ for 3 months, reduced to $50 \mathrm{mg}$ per day or every other day for 12 months [120]. After 1 year, relapses were $38.5 \%$ in the first group and $12 \%$ in the second group [120]. Another cohort study [121] showed lower cumulative relapse rates and lower corticosteroid dosage in patients treated with corticosteroid plus corticosteroid-sparing immunosuppressants than in patients treated with corticosteroids alone. These results support the use of immunosuppressive agents in patients who are more likely to relapse or who need long-term corticosteroid therapy [11], as well as in some patients who have obesity, glucose intolerance, diabetes, hypertension, osteoporosis, and other relative contraindications to prolonged courses of corticosteroids [116]. A recent network metaanalysis showed that treatment with corticosteroids and 
Table 6. Clinical Entities With Potentially Increased Tissue IgG4+ Plasma Cell Counts

\begin{tabular}{|c|c|}
\hline Disease Group & Clinical Entities \\
\hline $\begin{array}{l}\text { Systemic } \\
\text { diseases }\end{array}$ & $\begin{array}{l}\text { Rheumatoid arthritis }[27,29] \\
\text { Sjögren syndrome }[11,29] \\
\text { Systemic sclerosis [29] } \\
\text { Sarcoidosis/sarcoid-like disease }[11,29] \\
\text { Histiocytosis (Rosai-Dorfman disease, } \\
\text { Erdheim-Chester disease) }[11,27,29]\end{array}$ \\
\hline Vasculitis & $\begin{array}{l}\text { Eosinophilic granulomatous with polyangiitis } \\
\text { (Churg-Strauss disease) }[11,27,29] \\
\text { Granulomatosis with polyangiitis } \\
\text { (Wegener disease) }[11,27,29] \\
\text { Microscopic polyangiitis }[11,29] \\
\text { Hypocomplementemic urticarial vasculitis [27] } \\
\text { Aortitis caused by chronic } \\
\text { Staphylococcus aureus infection [27] }\end{array}$ \\
\hline $\begin{array}{l}\text { Hematological } \\
\text { malignancies } \\
\text { and diseases }\end{array}$ & $\begin{array}{l}\text { Lymphomas: follicular [11,27], } \\
\text { lymphoplasmacytic [11], } \\
\text { angioimmunoblastic [27], MALT [29], } \\
\text { extranodal marginal zone [11,27] } \\
\text { Castleman disease [11,27,29] } \\
\text { Plasmacytosis [29] } \\
\text { Follicular hyperplasia (lymph node) [29] } \\
\text { Kimura disease [29] }\end{array}$ \\
\hline $\begin{array}{l}\text { Solid-organ } \\
\text { neoplasms }\end{array}$ & $\begin{array}{l}\text { Adenocarcinoma (peritumoral } \\
\text { infiltrate/mixed) }[11,29] \\
\text { Squamous cell carcinoma (peritumoral } \\
\text { infiltrate/mixed) }[11,29] \\
\text { Pancreatic cancer }[27,29] \\
\text { Cholangiocarcinoma }[29] \\
\text { Lung cancer [27] } \\
\text { Sarcoma [27] }\end{array}$ \\
\hline Benign tumors & $\begin{array}{l}\text { Inflammatory myofibroblastic tumor [11] } \\
\text { Splenic sclerosing angiomatoid nodular } \\
\text { transformation [11] } \\
\text { Xanthogranuloma [11] }\end{array}$ \\
\hline Infections & $\begin{array}{l}\text { Pulmonary abscess [27] } \\
\text { Epstein-Barr virus-related lymphadenopathy [27] } \\
\text { Infectious mastoiditis [30] } \\
\text { Rhinosinusitis/chronic sinusitis }[11,29]\end{array}$ \\
\hline $\begin{array}{l}\text { Digestive } \\
\text { diseases }\end{array}$ & $\begin{array}{l}\text { Plasma-cell hepatitis (allograft-related } \\
\text { autoimmune hepatitis) [29] } \\
\text { Autoimmune hepatitis [29] } \\
\text { Primary sclerosing cholangitis [11] } \\
\text { Obstructive pancreatitis [29] } \\
\text { Chronic pancreatitis [29] } \\
\text { Inflammatory bowel disease [11,27,29] } \\
\text { Diverticulitis [27,29] }\end{array}$ \\
\hline Oral diseases & $\begin{array}{l}\text { Radicular cysts [29] } \\
\text { Epulis plasmacellularis [29] } \\
\text { Oral lichen ruber [29] } \\
\text { Chronic tonsillitis [29] }\end{array}$ \\
\hline Skin diseases & $\begin{array}{l}\text { Cutaneous plasmacytosis [11] } \\
\text { Perforating collagenosis [11] }\end{array}$ \\
\hline $\begin{array}{l}\text { Ophthalmic } \\
\text { diseases }\end{array}$ & $\begin{array}{l}\text { Chalazion [29] } \\
\text { Nonspecific orbital inflammatory disease [29] }\end{array}$ \\
\hline Miscellaneous & $\begin{array}{l}\text { Nonspecific synovitis [29] } \\
\text { Kidney allograft rejection [29] } \\
\text { Idiopathic neuropathy [29] }\end{array}$ \\
\hline
\end{tabular}

Abbreviation: MALT, mucosa-associated lymphoid tissue. immunosuppressive agents was associated with a lower relapse rate than corticosteroids alone and a higher remission rate than those given corticosteroids, immunosuppressive agents in monotherapy, or rituximab induction therapy only [122].

Rituximab, an anti-CD20 biologic agent, has been proposed as an option whenever corticosteroids or immunosuppressive agents are unsuccessful $[43,123,124]$. It could also be a firstline treatment in specific situations. An uncontrolled trial of 30 patients treated with rituximab ( 2 intravenous doses of $1 \mathrm{~g}$ separated by 15 days) showed improvement in $97 \%$ of patients (47\% complete remission) at 6 months [125]. In another retrospective multicenter study of 33 patients, clinical relapse-free survival was 21 months in those treated with a single course of rituximab and 41 months in those treated with a systematic maintenance retreatment [126]. Rituximab can be used as maintenance therapy. A recent meta-analysis showed its efficacy in reducing the relapse rate compared with corticosteroids and immunosuppressive agents [122]. However, the optimal frequency and duration of the treatment remain unknown. Additional biological drugs such as infliximab [127] and abatacept have been used successfully in a very small number of cases of IgG4-RD.

The IgG4-RD Responder Index was designed, updated, and validated to measure involvement, extent, and progress of the disease $[128,129]$. In the case of relapse or new outbreaks of IgG4-RD, the first option is to retreat with corticosteroids and evaluate the use of corticosteroid-sparing immunosuppressive agents or rituximab [11].

\section{Prognosis of IgG4-Related Disease}

Given that IgG4-RD was first described relatively recently [2], its natural history is not completely known. Inflammation and fibrosis are responsible for the morbidity and mortality of the disease, particularly when vital organs are affected, as in pancreatitis, kidney failure, ruptured aneurysm, and meningitis [130]. The risk of recurrence or relapse is high. Without ongoing maintenance therapy, between $30 \%$ and $60 \%$ of patients relapse within 3-6 months of discontinuing corticosteroid monotherapy [131,132]. In patients treated with rituximab, the rate of relapse is 0.39 per person-year [89]. However, other studies have shown lower rates of relapse. Predictors of relapse in IgG4-RD are high baseline values of $\operatorname{IgG} 4, \operatorname{IgE}$, and total eosinophil count $[89,90,121]$. Furthermore, for each of these predictors, the higher the baseline value, the greater the risk of relapse and the shorter the time to relapse [89]. However, the use of serum IgG4 concentrations in the longitudinal care of patients is an imperfect means of determining the presence of relapse $[89,91,133]$. Blood plasmablast levels appear to be more useful for that purpose $[99,103,104]$. Other predictors of relapse include involvement of more organs, higher IgG4 Responder Index scores, history of allergy, complete drug withdrawal, low corticosteroid maintenance dosage [121], and increased circulating memory B cells after 6 months of corticosteroid treatment [134].

IgG4-RD may be associated with other diseases. The potential association between IgG4-RD and cancer is controversial; some studies have suggested such a 
relationship [52,130,135-137], whereas others have not $[138,139]$. An association between Ig4-RD and cerebral aneurysms has also been described [139]. Some data suggest that morbidity and all-cause mortality among patients with IgG4-RD is higher than expected [130], whereas others do not [139].

\section{IgG4-Related Disease and Allergy}

The relationship between IgG4-RD and allergy is both intriguing and controversial. Allergic diseases and IgG4$\mathrm{RD}$ have many features in common, including (see above) activation of $\mathrm{T}_{\mathrm{H}} 2$ cells, increased $\mathrm{T}_{\mathrm{H}} 2$ cytokines [35], increased serum IgE concentrations, blood and tissue eosinophilia, mast-cell infiltration and activation, and elevation of serum IgG4 itself.

Serum IgE concentrations are significantly higher among patients with IgG4-RD than in healthy controls [82]. Increased serum $\operatorname{IgE}$ concentrations can be observed in one- to two-thirds of patients with IgG4-RD [27,32,82-84] and sometimes in an even greater proportion $[85,87,88]$. Moreover, serum IgE concentrations may have diagnostic value for IgG4-RD. In their study comparing 48 patients with IgG4-RD and 42 controls with various diseases and elevated serum IgG4, Culver et al [82] found that IgE $>480 \mathrm{kU} / \mathrm{L}$ at diagnosis distinguished patients with IgG4-RD from controls with $86 \%$ specificity, $36 \%$ sensitivity, and a likelihood ratio of 3.2. Serum IgE may also represent a useful serological marker in distinguishing IgG4 retroperitoneal fibrosis from idiopathic retroperitoneal fibrosis [140]. Serum IgE concentrations tend to decrease in parallel with serum IgG4 concentrations shortly after therapy in patients with IgG4-RD, both with corticosteroids [82] and with rituximab $[89,141]$. Furthermore, increased serum IgE concentrations may add prognostic value in patients with IgG4-RD $[82,89]$. A serum IgE level $>380 \mathrm{kU} / \mathrm{L}$ at diagnosis identified patients whose disease relapsed after therapy with $88 \%$ specificity, $64 \%$ sensitivity, and a likelihood ratio of 5.4 , thus defining a subset of patients requiring careful follow-up [82]. A study of IgG4-related kidney disease identified serum IgE level as a risk factor for renal atrophy [142].

Peripheral blood eosinophil count is higher in patients with IgG4-RD than in healthy controls [82], and peripheral eosinophilia is present in around $20 \%-40 \%$ of patients with IgG4-RD [27,32,82-85,143]. Tissue eosinophilia is also present in up to $51 \%-86 \%$ of samples of patients with IgG4RD $[27,82]$. Circulating levels of eosinophils are associated with [143] male predominance, increased prevalence of dacryoadenitis, sialadenitis, lymphadenopathy, skin rash, greater organ involvement, higher peripheral white blood cell count, erythrocyte sedimentation rate, and serum $\mathrm{IgG}$, IgG1, IgG3, IgG4, IgG4/IgG ratio, and IgE, while lower levels of serum $\operatorname{IgG} 2$, IgA and C4, as well as a higher IgG4RD Responder Index, longer disease duration, and [89,143] increased risk of relapse. However, they are not associated with the incidence of allergic disease [143]. In addition, IgE-positive mast cells are present in at least $50 \%$ of tissue samples and further indicate an IgE-mediated response in IgG4-RD [82,144].
The frequency of allergic disease among patients with IgG4-RD is not entirely known. Comparison of the prevalence of allergy between studies is limited by the lack of uniform definitions for allergic disease and atopy. In the comprehensive study of Culver et al [82], allergic sensitization to aeroallergens (as revealed by positive specific IgE to a mixture of aeroallergens) was present in $52 \%(25 / 48)$ of patients with IgG4-RD. Moreover, $40 \%$ of patients with IgG4-RD were strictly classified as atopic, because they also had respiratory symptoms. Furthermore, a clinical history of allergic disease was significantly more common among patients with IgG4-RD than in healthy controls [82], as has been suggested in several studies showing a 30\%-40\% prevalence of allergy among patients with IgG4-RD [32,33,145,146]. Other studies showed an even greater prevalence $[85,88,147,148]$. Intriguingly, allergic disease is more common among patients with IgG4-RD and upper body organ involvement [145], especially the salivary gland, but also ear, nose, and throat disease [85,148,149], which could point to a food or inhalant allergen as a trigger, particularly considering that most of these patients have respiratory allergy [148]. IgG4-RD is associated with a polyclonal IgG4 response to multiple food antigens $[26,150]$, although IgG4-RD was not associated with the presence of specific IgE. However, studies of allergic sensitization in this setting are scarce [82], and, to the best of our knowledge, no studies of allergic sensitization, as defined by positivity to a panel of skin prick tests, have been performed in IgG4-RD.

Taken together, the above-mentioned features could indicate a role for allergic responses in the pathogenesis of IgG4-RD. However, accurate analysis of circulating T-cell subsets has led to conflicting results and revealed expansion of $\mathrm{T}_{\mathrm{H}} 2$ memory $\mathrm{CD}^{+} \mathrm{T}$ cells only in IgG4-RD patients with a concomitant history of atopy [33]. Of note, eosinophilia and elevated IgE have also been observed in IgG4-RD patients with and without allergic disease $[32,82,84,85,87,140]$ and are probably induced by processes inherent to IgG4-RD itself (eg, $\mathrm{T}_{\mathrm{H}} 2$ cytokines, such as IL-4 and IL-5) rather than allergy per se $[32,82,140]$. This could indicate that $\mathrm{T}_{\mathrm{H}} 2$-related features are an epiphenomenon of $\mathrm{T}_{\mathrm{H}} 2$ activation that is not allergymediated [33]. An intriguing alternative hypothesis is that IgG4-RD could represent a late stage of allergic disease. Of note, allergic disease (particularly atopy-related disease) is common in the young, whereas IgG4-RD is more common in older adults. Indeed, the profile of increased serum IgG4 and enhanced regulatory cytokines (IL-10 and TGF- $\beta$ ) resembles the immune status that develops after immunotherapy for allergic diseases. Future studies are needed to evaluate the prevalence of positive skin prick test results in patients with IgG4-RD. Moreover, future studies are needed to evaluate the potential incidence of IgG4-RD in cohorts of allergic patients with and without specific immunotherapy (Figure 2).

Whatever the potential link between IgG4-RD and allergic disorders, the red flags that prompt the diagnosis of IgG4-RD should be taken into consideration [82]. A history of allergy or atopy, elevated serum IgE, and blood and tissue eosinophilia are hallmarks of IgG4-RD that are obviously common in patients attending allergy clinics. IgG4-RD should be suspected in patients with a history of unexplained swelling in 1 or more organs, particularly in corticosteroid-sensitive patients and in males in the sixth decade of life and beyond [82]. 


\section{Funding}

This work was supported by 2 grants (PI16/01404 and Río Hortega Research Grant, CM17/00113) and by the Spanish Network for Addictive Disorders (Red de Trastornos Adictivos, RD16/0017/0018), from the Carlos III Institute of Health (Instituto de Salud Carlos III, Spanish Ministry of Health). Co-funding was received from FEDER (Fondo Europeo de Desarrollo Regional).

This article was drafted within the Clinical Research in Medicine PhD program of the University of Santiago de Compostela.

\section{Conflicts of Interest}

The authors declare that they have no conflicts of interest.

\section{References}

1. Stone JH, Zen Y, Deshpande V. IgG4-related disease. N Engl J Med. 2012;366:539-51.

2. Kamisawa T, Funata N, Hayashi Y, Eishi Y, Koike M, Tsuruta $K$, et al. A new clinicopathological entity of lgG4-related autoimmune disease. J Gastroenterol. 2003;38:982-4.

3. Hamano H, Kawa S, Horiuchi A, Unno H, Furuya N, Akamatsu $\mathrm{T}$, et al. High serum IgG4 concentrations in patients with sclerosing pancreatitis. N Engl J Med. 2001;344:732-8.

4. Stone JH, Khosroshahi A, Deshpande V, Chan JK, Heathcote $J G$, Aalberse R, et al. Recommendations for the nomenclature of IgG4-related disease and its individual organ system manifestations. Arthritis Rheum. 2012;64:3061-7.

5. Chang J, Zhang W. Infrequent organ involvement of IgG4related diseases: a literature review. Clin Rheumatol. 2018;37:1153-9.

6. Moteki H, Yasuo M, Hamano H, Uehara T, Usami S. IgG4related chronic rhinosinusitis: a new clinical entity of nasal disease. Acta Otolaryngol. 2011;131:518-26.

7. Brito-Zerón $P$, Ramos-Casals M, Bosch X, Stone JH. The clinical spectrum of IgG4-related disease. Autoimmun Rev. 2014;13:1203-10.

8. Divatia MK, Ro JY. IgG4-related disease of the genitourinary tract. J Interdiscipl Histopathol. 2014;2:3-18.

9. Ichiki A, Hashimoto N, Ueda T, Hiraiwa S, Tajiri T, Nakamura N, et al. IgG4-related disease with bone marrow involvement. Intern Med. 2016;55:2295-9.

10. Deshpande V, Zen Y, Chan JK, Yi EE, Sato Y, Yoshino T, et al. Consensus statement on the pathology of IgG4-related disease. Mod Pathol. 2012;25:1181-92.

11. Khosroshahi A, Wallace ZS, Crowe JL, Akamizu T, Azumi A, Carruthers MN, et al. International consensus guidance statement on the management and treatment of IgG4-related disease. Arthritis Rheumatol. 2015;67:1688-99.

12. Wallace ZS, Naden RP, Chari S, Choi H, Della-Torre E, Dicaire JF, et al. The 2019 American College of Rheumatology/European League Against Rheumatism Classification Criteria for lgG4Related Disease. Arthritis Rheumatol. 2020;72:7-19.

13. Uchida K, Masamune A, Shimosegawa T, Okazaki K. Prevalence of IgG4-related disease in Japan based on nationwide survey in 2009. Int J Rheumatol. 2012;2012:358371.
14. Karim F, Loeffen J, Bramer W, Westenberg L, Verdijk R, van Hagen M, et al. IgG4-related disease: a systematic review of this unrecognized disease in pediatrics. Pediatr Rheumatol Online J. 2016;14:18.

15. Yamamoto $M$, Yajima $H$, Takahashi H, Yokoyama Y, Ishigami $\mathrm{K}$, Shimizu Y, et al. Everyday clinical practice in IgG4-related dacryoadenitis and/or sialadenitis: results from the SMART database. Mod Rheumatol. 2015;25:199-204.

16. Wallace ZS, Zhang Y, Perugino CA, Naden R, Choi HK, Stone $\mathrm{JH}$; ACR/EULAR IgG4-RD classification criteria committee. Clinical phenotypes of IgG4-related disease: an analysis of two international cross-sectional cohorts. Ann Rheum Dis. 2019;78:406-12.

17. Wang L, Zhang P, Zhang $X$, Lin W, Tang H, Li J, et al. Sex disparities in clinical characteristics and prognosis of immunoglobulin G4-related disease: a prospective study of 403 patients. Rheumatology (Oxford). 2019;58:820-30.

18. Carballo I, Alvela L, Pérez LF, Gude F, Vidal C, Alonso M, et al. Serum concentrations of IgG4 in the Spanish adult population: relationship with age, gender, and atopy. PLoS One. 2016;11:e0149330.

19. Mahajan VS, Mattoo H, Deshpande V, Pillai SS, Stone JH. IgG4related disease. Annu Rev Pathol. 2014;9:315-47.

20. Aalberse RC, StapelSO, Schuurman J, RispensT. Immunoglobulin G4: an odd antibody. Clin Exp Allergy. 2009;39:469-77.

21. Davies AM, Sutton BJ. Human IgG4: a structural perspective. Immunol Rev. 2015;268:139-59.

22. Wachholz PA, Soni NK, Till SJ, Durham SR. Inhibition of allergen-IgE binding to $B$ cells by $\lg G$ antibodies after grass pollen immunotherapy. J Allergy Clin Immunol. 2003;112:91522.

23. Carballo I, Carballada F, Nuñez-Orjales R, Vidal C, GonzalezQuintela A. Total and bee venom-specific serum IgG4 and IgE in beekeepers. J Investig Allergol Clin Immunol. 2017;27:1468.

24. Ozdemir C, Kucuksezer UC, Akdis M, Akdis CA. Mechanisms of aeroallergen immunotherapy: subcutaneous immunotherapy and sublingual immunotherapy. Immunol Allergy Clin North Am. 2016;36:71-86.

25. Palomares 0 . The role of regulatory $T$ cells in IgE-mediated food allergy. J Investig Allergol Clin Immunol. 2013;23:37182.

26. Culver EL, Vermeulen E, Makuch E, van Leeuwen A, Sadler $R$, Cargill $T$, et al. Increased lgG4 responses to multiple food and animal antigens indicate a polyclonal expansion and differentiation of pre-existing B cells in IgG4-related disease. Ann Rheum Dis. 2015;74:944-47.

27. Stone JH, Brito-Zerón P, Bosch X, Ramos-Casals M. Diagnostic approach to the complexity of IgG4-related disease. Mayo Clin Proc. 2015;90:927-39.

28. Yu KH, Chan TM, Tsai PH, Chen CH, Chang PY. Diagnostic performance of serum lgG4 levels in patients with IgG4related disease. Medicine (Baltimore). 2015;94:e1707.

29. Brito-Zerón P, Bosch X, Ramos-Casals M, Stone JH. IgG4related disease: advances in the diagnosis and treatment. Best Pract Res Clin Rheumatol. 2016;30:261-78.

30. Deshpande $\mathrm{V}$, Zane NA, Kraft $\mathrm{S}$, Stone $J H$, Faquin WC Recurrent mastoiditis mimics lgG4 related disease: a potential diagnostic pitfall. Head Neck Pathol. 2016;10:314-20. 
31. Umehara H, Okazaki $\mathrm{K}$, Kawano M, Tanaka Y. The front line of research into immunoglobin G4-related disease - Do autoantibodies cause immunoglobin G4-related disease? Mod Rheumatol. 2019;29:214-8.

32. Della-Torre E, Mattoo H, Mahajan VS, Carruthers M, Pillai S, Stone $\mathrm{JH}$. Prevalence of atopy, eosinophilia, and IgE elevation in IgG4-related disease. Allergy. 2014;69:269-72.

33. Mattoo H, Della-Torre E, Mahajan VS, Stone JH, Pillai S. Circulating Th2 memory cells in IgG4-related disease are restricted to a defined subset of subjects with atopy. Allergy. 2014;69:399-402.

34. Della-Torre E, Lanzillotta M, Doglioni C. Immunology of IgG4related disease. Clin Exp Immunol. 2015;181:191-206.

35. Zen Y, Fujii T, Harada K, Kawano M, Yamada K, Takahira M, et al. Th2 and regulatory immune reactions are increased in immunoglobin G4-related sclerosing pancreatitis and cholangitis. Hepatology. 2007;45:1538-46.

36. Shiokawa M, Kodama Y, Kuriyama K, Yoshimura K, Tomono T, Morita $T$, et al. Pathogenicity of lgG in patients with lgG4related disease. Gut. 2016;65:1322-32.

37. Umehara H, Nakajima A, Nakamura T, Kawanami T, Tanaka M, Dong L, et al. IgG4-related disease and its pathogenesis-crosstalk between innate and acquired immunity. Int Immunol. 2014;26:585-95.

38. de Buy Wenniger LJ, Culver EL, Beuers U. Exposure to occupational antigens might predispose to IgG4-related disease. Hepatology. 2014;60:1453-4.

39. Deshpande V, Chicano S, Finkelberg D, Selig MK, MinoKenudson M, Brugge WR, et al. Autoimmune pancreatitis: a systemic immune complex mediated disease. Am J Surg Pathol. 2006;30:1537-45.

40. Mattoo H, Mahajan VS, Maehara T, Deshpande V, Della-Torre E, Wallace ZS, et al. Clonal expansion of CD4(+) cytotoxic T lymphocytes in patients with IgG4-related disease. J Allergy Clin Immunol. 2016;138:825-38.

41. Maehara $T$, Mattoo $H$, Ohta M, Mahajan VS, Moriyama $M$, Yamauchi $M$, et al. Lesional CD4+ IFN- $\gamma+$ cytotoxic T lymphocytes in IgG4-related dacryoadenitis and sialoadenitis. Ann Rheum Dis. 2017;76:377-85.

42. Mattoo H, Stone JH, Pillai S. Clonally expanded cytotoxic $\mathrm{CD} 4+\mathrm{T}$ cells and the pathogenesis of IgG4-related disease. Autoimmunity. 2017;50:19-24.

43. Khosroshahi A, Bloch D, Deshpande V, Stone JH. Rituximab therapy leads to rapid decline of serum lgG4 levels and prompt clinical improvement in lgG4-related systemic disease. Arthritis Rheum. 2010;62:1755-62.

44. Maehara T, Moriyama M, Nakashima H, Miyake K, Hayashida J-N, Tanaka A, et al. Interleukin-21 contributes to germinal centre formation and immunoglobulin $\mathrm{G} 4$ production in lgG4related dacryoadenitis and sialoadenitis, so-called Mikulicz's disease. Ann Rheum Dis. 2012;71:2011-20.

45. Ettinger $R$, Kuchen $S$, Lipsky PE. Interleukin 21 as a target of intervention in autoimmune disease. Ann Rheum Dis. 2008;67 Suppl 3:iii83-6.

46. Tsuboi H, Matsuo N, lizuka M, Tsuzuki S, Kondo Y, Tanaka A, et al. Analysis of IgG4 class switch-related molecules in lgG4related disease. Arthritis Res Ther. 2012;14:R171.

47. Zen Y, Fujii T, Harada K, Kawano M, Yamada K, Takahira M, et al. Th2 and regulatory immune reactions are increased in immunoglobin G4-related sclerosing pancreatitis and cholangitis. Hepatology. 2007;45:1538-46.

48. Vasaitis L. IgG4-related disease: A relatively new concept for clinicians. Eur J Intern Med. 2016;27:1-9.

49. Ishikawa Y, Terao C. Genetic analysis of IgG4-related disease. Mod Rheumatol. 2020;30:17-23.

50. McHugh J. Two GWAS loci identified in IgG4-related disease. Nat Rev Rheumatol. 2019;15:574.

51. Nakamura T, Satoh-Nakamura T, Nakajima A, Kawanami T, Sakai T, Fujita Y, et al. Impaired expression of innate immunity-related genes in IgG4-related disease: a possible mechanism in the pathogenesis of IgG4-RD. Mod Rheumatol. 2019;11:1-7.

52. Wallace ZS, Wallace CJ, Lu N, Choi HK, Stone JH. Association of IgG4-related disease with history of malignancy. Arthritis Rheumatol. 2016;68:2283-9.

53. Khosroshahi A, Stone JH. A clinical overview of IgG4-related systemic disease. Curr Opin Rheumatol. 2011;23:57-66.

54. Kamisawa T, Zen Y, Pillai S, Stone JH. IgG4-related disease. Lancet. 2015;385:1460-71.

55. Martínez-Valle F, Fernández-Codina A, Pinal-Fernández I, OrozcoGálvez O, Vilardell-Tarrés M. IgG4-related disease: evidence from six recent cohorts. Autoimmun Rev. 2017;16:168-72.

56. Kim KP, Kim MH, Song MH, Lee SS, Seo DW, Lee SK. Autoimmune chronic pancreatitis. Am J Gastroenterol. 2004;99:1605-16.

57. Takuma K, Kamisawa T, Gopalakrishna R, Hara S, Tabata T, Inaba Y, et al. Strategy to differentiate autoimmune pancreatitis from pancreas cancer. World J Gastroenterol. 2012;18:101520.

58. Vlachou PA, Khalili K, Jang HJ, Fischer S, Hirschfield GH, Kim TK. IgG4-related sclerosing disease: autoimmune pancreatitis and extrapancreatic manifestations. Radiographics 2011;31:1379402.

59. Wallace ZS, Deshpande V, Stone JH. Ophthalmic manifestations of IgG4-related disease: single-center experience and literature review. Semin Arthritis Rheum. 2014;43:806-17.

60. Wu A, Andrew NH, McNab AA, Selva D. IgG4-related ophthalmic disease: pooling of published cases and literature review. Curr Allergy Asthma Rep. 2015;15:27.

61. Fernández-Codina A, Martínez-Valle F, Pinilla B, López C, DeTorres I, Solans-Laqué $R$, et al. IgG4-related disease: results from a multicenter Spanish registry. Medicine (Baltimore). 2015;94:e1275.

62. Stone JR. Aortitis, periaortitis, and retroperitoneal fibrosis, as manifestations of IgG4-related systemic disease. Curr Opin Rheumatol. 2011;23:88-94.

63. Khosroshahi A, Carruthers MN, Stone JH, Shinagare S, Sainani N, Hasserjian RP, et al. Rethinking Ormond's disease: "idiopathic" retroperitoneal fibrosis in the era of IgG4-related disease. Medicine (Baltimore). 2013;92:82-91.

64. Mizushima I, Kasashima S, Fujinaga Y, Kawano M, Ishizaka N. IgG4-related periaortitis/periarteritis: an under-recognized condition that is potentially life-threatening. Mod Rheumatol. 2019;29:240-50.

65. Zen Y, Inoue D, Kitao A, Onodera M, Abo H, Miyayama S, et al. IgG4-related lung and pleural disease: a clinicopathologic study of 21 cases. Am J Surg Pathol. 2009;33:1886-93.

66. Inoue D, Zen Y, Abo H, Gabata T, Demachi H, Kobayashi T, et al. Immunoglobulin G4-related lung disease: CT findings with pathologic correlations. Radiology. 2009;251:260-70. 
67. Saeki T, Nishi S, Imai N, Ito T, Yamazaki H, Kawano M, et al. Clinicopathological characteristics of patients with lgG4related tubulointerstitial nephritis. Kidney Int. 2010;78:101623.

68. Alexander MP, Larsen CP, Gibson IW, Nasr SH, Sethi S, Fidler $M E$, et al. Membranous glomerulonephritis is a manifestation of IgG4-related disease. Kidney Int. 2013;83:455-62.

69. Zen Y, Nakanuma Y. IgG4-related disease: a cross-sectional study of 114 cases. Am J Surg Pathol. 2010;34:1812-9.

70. Cheuk W, Yuen HK, Chu SY, Chiu EK, Lam LK, Chan JK. Lymphadenopathy of IgG4-related sclerosing disease. Am J Surg Pathol. 2008;32:671-81.

71. Dahlgren M, Khosroshahi A, Nielsen GP, Deshpande V, Stone $J H$. Riedel's thyroiditis and multifocal fibrosclerosis are part of the IgG4-related systemic disease spectrum. Arthritis Care Res (Hoboken). 2010;62:1312-8.

72. Deshpande V, Huck A, Ooi E, Stone JH, Faquin WC, Nielsen GP. Fibrosing variant of Hashimoto thyroiditis is an IgG4 related disease. J Clin Pathol. 2012;65:725-8.

73. Lu LX, Della-Torre E, Stone JH, Clark SW. IgG4-related hypertrophic pachymeningitis: clinical features, diagnostic criteria, and treatment. JAMA Neurol. 2014;71:785-93.

74. Decker L, Crawford AM, Lorenzo G, Stippler M, Konstantinov KN, SantaCruz K. IgG4-related hypophysitis: case report and literature review. Cureus. 2016;8:e907.

75. Hanaoka M, Kammisawa T, Koizumi S, Kuruma S, Chiba K, Kikuyama M, et al. Clinical features of IgG4-related rhinosinusitis. Adv Med Sci. 2017;62:393-7.

76. Obiorah I, Hussain A, Palese C, Azumi N, Benjamin S, Ozdemirli M. IgG4-related disease involving the esophagus: a clinicopathological study. Dis Esophagus. 2017;30:1-7.

77. Takanashi S, Akiyama M, Suzuki K, Otomo K, Takeuchi T. IgG4related fibrosing mediastinitis diagnosed with computed tomography-guided percutaneous needle biopsy: Two case reports and a review of the literature. Medicine (Baltimore). 2018;97:e10935

78. Mori K, Yamada K, Konno T, Inoue D, Uno Y, Watanabe M, et al. Pericardial Involvement in IgG4-related disease. Intern Med. 2015:54:1231-5.

79. Cheuk W, Chan AC, Lam WL, Chow SM, Crowley P, Lloydd R, et al. IgG4-related sclerosing mastitis: description of a new member of the IgG4-related sclerosing diseases. Am J Surg Pathol. 2009;33:1058-64.

80. Bourlon MT, Sánchez-Ávila M, Chablé-Montero F, Arceo-Olaiz R. IgG4-related autoimmune prostatitis: is it an unusual or underdiagnosed manifestation of lgG4-related disease? Case Rep Urol. 2013;2013:295472.

81. Charrow A, Imadojemu S, Stephen S, Ogunleye T, Takeshita J, Lipoff JB. Cutaneous manifestations of IgG4-related disease (RD): A systematic review. J Am Acad Dermatol. 2016;75:197-202.

82. Culver EL, Sadler R, Bateman AC, Makuch M, Cargill T, Ferry B, et al. Increases in lgE, eosinophils, and mast cells can be used in diagnosis and to predict relapse of IgG4-related disease. Clin Gastroenterol Hepatol. 2017;15:1444-52.

83. Kamisawa $T$, Anjiki $H$, Egawa N, Kubota N. Allergic manifestations in autoimmune pancreatitis. Eur J Gastroenterol Hepatol. 2009;21:1136-39.

84. Campochiaro C, Ramirez GA, Bozzolo EP, Lanzillotta M, Berti A, Baldissera $E$, et al. IgG4-related disease in Italy: clinical features and outcomes of a large cohort of patients. Scand J Rheumatol. 2016;45:135-45.

85. Chen Y, Zhao JZ, Feng RE, Shi JH, Li XM, Fei YY, et al. Types of organ involvement in patients with immunoglobulin G4related disease. Chin Med J (Engl). 2016;129:1525-32.

86. Wallace ZS, Deshpande V, Mattoo H, Mahajan VS, Kulikova M, Pillai S, et al. IgG4-related disease: clinical and laboratory features in one hundred twenty-five patients. Arthritis Rheumatol. 2015;67:2466-75.

87. Hirano K, Tada M, Isayama H, Kawakubo K, Yagioka H, Sasaki $\mathrm{T}$, et al. Clinical analysis of high serum IgE in autoimmune pancreatitis. World J Gastroenterol. 2010;16:5241-6.

88. Lin W, Lu S, Chen $H, W u$ Q, Fei $Y$, Li M, et al. Clinical characteristics of immunoglobulin G4-related disease: a prospective study of 118 Chinese patients. Rheumatology (Oxford). 2015;54:1982-90.

89. Wallace ZS, Mattoo H, Mahajan VS, Kulikova M, Lu L, Deshpande $V$, et al. Predictors of disease relapse in lgG4related disease following rituximab. Rheumatology (Oxford). 2016;55:1000-8.

90. Tsang KFP, Oppong WK, Leeds SJ, Bekkali LHN, Nayar KM. Does IgG4 level at the time of diagnosis correlate with disease outcome in IgG4-related disease? Pancreatology. 2019;19:177-81.

91. Tabata T, Kamisawa T, Takuma K, Egawa N, Setoguchi K, Tsuruta K, et al. Serial changes of elevated serum IgG4 levels in IgG4-related systemic disease. Intern Med. 2011;50:69-75.

92. Umehara H, Okazaki K, Masaki Y, Kawano M, Yamamoto $M$, Saeki $T$, et al. Comprehensive diagnostic criteria for IgG4-related disease (IgG4-RD), 2011. Mod Rheumatol. 2012;22:21-30.

93. Sarnago A, Pascual RM, Moreno MJ, Laíz B, Fuster O. IgG subclasses quantitation: Analytical performance of The Binding Site SPAPLUS $®$ human assay and comparison with Siemens BNII $®$ assay. Clin Biochem. 2018;51:85-9.

94. Khosroshahi A, Cheryk LA, Carruthers MN, Edwards JA, Bloch DB, Stone JH. Brief report: spuriously low serum lgG4 concentrations caused by the prozone phenomenon in patients with IgG4-related disease. Arthritis Rheumatol. 2014;66:213-7

95. Harkness T, Fu X, Zhang Y, Choi H, Stone J, Blumenthal K, et al. Serum IgG4 Concentrations Differ According to Race and Sex [abstract]. Arthritis Rheumatol. 2019;71(suppl 10).

96. Carruthers MN, Khosroshahi A, Augustin T, Deshpande $V_{\text {, }}$ Stone JH. The diagnostic utility of serum IgG4 concentrations in IgG4-related disease. Ann Rheum Dis. 2015;74:14-8.

97. Xia CS, Fan CH, Liu YY. Diagnostic performances of serum IgG4 concentration and IgG4/lgG ratio in IgG4-related disease. Clin Rheumatol. 2017;36:2769-74.

98. Kawa $S$, Ito $T$, Watanabe $T$, Maruyama $M$, Hamano $H_{\text {, }}$ Maruyama $\mathrm{M}$, et al. The utility of serum IgG4 concentrations as a biomarker. Int J Rheumatol. 2012;2012:198314.

99. Wallace ZS, Mattoo H, Carruthers M, Mahajan VS, Della Torre $\mathrm{E}$, Lee $\mathrm{H}$, et al. Plasmablasts as a biomarker for IgG4-related disease, independent of serum lgG4 concentrations. Ann Rheum Dis. 2015;74:190-5.

100. Qi R, Chen LYC, Park S, Irvine R, Seidman MA, Kelsall JT, et al. Utility of serum IgG4 levels in a multiethnic population. Am J Med Sci. 2018;355:61-6. 
101. Li C, Xiang Y, Wu X, Cao Y, Zhao Y, Sun X, et al. Serum IgG4 elevation in SAPHO syndrome: does it unmask a disease activity marker? Clin Exp Rheumatol. 2020;38:35-41.

102. Ghazale A, Chari ST, Smyrk TC, Levy MJ, Topazian MD, Takahashi $N$, et al. Value of serum IgG4 in the diagnosis of autoimmune pancreatitis and in distinguishing it from pancreatic cancer. Am J Gastroenterol 2007;102:1646-53.

103. Mattoo H, Mahajan VS, Della-Torre E, Sekigami $Y$, Carruthers M, Wallace ZS, et al. De novo oligoclonal expansions of circulating plasmablasts in active and relapsing lgG4-related disease. J Allergy Clin Immunol. 2014;134:679-87.

104. Lin W, Zhang P, Chen H, Chen Y, Yang H, Zheng W, et al. Circulating plasmablasts/plasma cells: a potential biomarker for lgG4-related disease. Arthritis Res Ther. 2017;19:25.

105. Doorenspleet ME, Hubers LM, Culver EL, Maillette de Buy Wenniger $L$, Klarenbeek PL, Chapman RW, et al. Immunoglobulin G4(+) B-cell receptor clones distinguish immunoglobulin $\mathrm{G}$ 4-related disease from primary sclerosing cholangitis and biliary/pancreatic malignancies. Hepatology. 2016;64:501-7.

106. Cargill T, Makuch M, Sadler R, Lighaam LC, Peters R, van Ham $M$, et al. Activated T-follicular helper 2 cells are associated with disease activity in IgG4-related sclerosing cholangitis and pancreatitis. Clin Transl Gastroenterol. 2019;10:e00020.

107. Martínez-de-Alegría A, Baleato-González S, García-Figueiras R, Bermúdez-Naveira A, Abdulkader-Nallib I, Díaz-Peromingo JA, et al. IgG4-related Disease from head to toe. Radiographics. 2015;35:2007-25.

108. Ohara H, Okazaki K, Tsubouchi H, Inui K, Kawa S, Kamisawa $\mathrm{T}$, et al. Clinical diagnostic criteria of IgG4-related sclerosing cholangitis 2012. J Hepatobiliary Pancreat Sci. 2012;19:536-42.

109. Takahashi N, Kawashima A, Fletcher JG, Chari ST. Renal involvement in patients with autoimmune pancreatitis: CT and MR imaging findings. Radiology. 2007;242:791-801.

110. Zhang P, Dyer RB. The "fat ring" sign of sclerosing mesenteritis. Abdom Radiol (NY). 2018;43:1839-40.

111. Katabathina VS, Khalil S, Shin S, Lath N, Menias CO, Prasad SR. Immunoglobulin G4-related disease: recent advances in pathogenesis and imaging findings. Radiol Clin North Am. 2016;54:535-51.

112. Zhao Z, Wang Y, Guan Z, Jin J, Huang F, Zhu J. Utility of FDG$\mathrm{PET} / \mathrm{CT}$ in the diagnosis of IgG4-related diseases. Clin Exp Rheumatol. 2016;34:119-25.

113. Lee J, Hyun SH, Kim S, Kim DK, Lee JK, Moon SH, et al. Utility of FDG PET/CT for differential diagnosis of patients clinically suspected of IgG4-related disease. Clin Nucl Med. 2016;41:e237-43.

114. Yamamoto M, Shimizu Y, Yajima H, Tabeya T, Suzuki C, Naishiro $Y$, et al. Validation of the comprehensive diagnostic criteria for IgG4-related disease in a SMART registry. Mod Rheumatol. 2016;26:310-2.

115. Masaki Y, Matsui S, Saeki T, Tsuboi H, Hirata S, Izumi Y, et al. A multicenter phase II prospective clinical trial of glucocorticoid for patients with untreated IgG4-related disease. Mod Rheumatol. 2017;27:849-54.

116. Della-Torre E, Stone JH. "How I manage" IgG4-Related Disease. J Clin Immunol. 2016;36:754-63.

117. Fernández-Codina $A$, Pinilla $B$, Pinal-Fernández I, López $C$, Fraile-Rodríguez G, Fonseca-Aizpuru $\mathrm{E}_{\text {, et al. Treatment and }}$ outcomes in patients with IgG4-related disease using the IgG4 responder index. Joint Bone Spine. 2018;85:721-6.

118. Shirakashi M, Yoshifuji H, Kodama Y, Chiba T, Yamamoto $M$, Takahashi $H$, et al. Factors in glucocorticoid regimens associated with treatment response and relapses of IgG4related disease: a multicentre study. Sci Rep. 2018;8:10262.

119. Yunyun F, Yu P, Panpan Z, Xia Z, Linyi P, Jiaxin Z, et al. Efficacy and safety of low dose mycophenolate mofetil treatment for immunoglobulin G4-related disease: a randomized clinical trial. Rheumatology (Oxford). 2019;58:52-60.

120. Yunyun F, Yu C, Panpan Z, Hua C, Di W, Lidan Z, et al. Efficacy of cyclophosphamide treatment for immunoglobulin G4related disease with addition of glucocorticoids. Sci Rep. 2017;7:6195.

121. Peng Y, Li JQ, Zhang PP, Zhang X, Peng LY, Chen $H$, et al. Clinical outcomes and predictive relapse factors of lgG4related disease following treatment: a long-term cohort study. J Intern Med. 2019;286:542-55.

122. Omar D, Chen Y, Cong Y, Dong L. Glucocorticoids and steroid sparing medications monotherapies or in combination for IgG4-RD: a systematic review and network meta-analysis. Rheumatology (Oxford). 2020;59:718-26.

123. Khosroshahi A, Carruthers MN, Deshpande V, Unizony S, Bloch $\mathrm{DB}$, Stone JH. Rituximab for the treatment of IgG4-related disease: lessons from 10 consecutive patients. Medicine (Baltimore). 2012;91:57-66.

124. Hart PA, Topazian MD, Witzig TE, Clain JE, Gleeson FC, Klebig $\mathrm{RR}$, et al. Treatment of relapsing autoimmune pancreatitis with immunomodulators and rituximab: the Mayo Clinic experience. Gut. 2013;62:1607-15.

125. Carruthers MN, Topazian MD, Khosroshahi A, Witzig TE, Wallace ZS, Hart PA, et al. Rituximab for IgG4-related disease: a prospective, open-label trial. Ann Rheum Dis. 2015;74:11717.

126. Ebbo M, Grados A, Samson M, Groh M, Loundou A, Rigolet $A$, et al. Long-term efficacy and safety of rituximab in IgG4related disease: Data from a French nationwide study of thirtythree patients. PLoS One. 2017;12:e0183844.

127. Karim F, Paridaens D, Westenberg LEH, Guenoun J, Verdijk RM, van Hagen PM, et al. Infliximab for IgG4-related orbital disease. Ophthalmic Plast Reconstr Surg. 2017;33(3S Suppl 1):S162-S165.

128. Carruthers MN, Stone JH, Deshpande V, Khosroshahi A. Development of an IgG4-RD responder index. Int J Rheumatol. 2012;2012:259408.

129. Wallace ZS, Khosroshahi A, Carruthers MD, Perugino CA, Choi $\mathrm{H}$, Campochiaro $\mathrm{C}$, et al. An international multispecialty validation study of the IgG4-related disease responder Index. Arthritis Care Res (Hoboken). 2018;70:1671-8.

130. Huggett MT, Culver EL, Kumar M, Hurst JM, Rodriguez-Justo M, Chapman MH, et al. Type 1 autoimmune pancreatitis and IgG4-related sclerosing cholangitis is associated with extrapancreatic organ failure, malignancy, and mortality in a prospective UK cohort. Am J Gastroenterol. 2014;109:167583.

131. Raina A, Yadav D, Krasinskas AM, McGrath KM, Khalid $A$, Sanders $M$, et al. Evaluation and management of autoimmune pancreatitis: experience at a large US center. Am J Gastroenterol. 2009;104:2295-306. 
132. Kamisawa T, Shimosegawa T, Okazaki K, Nishino T, Watanabe $\mathrm{H}$, Kanno A, et al. Standard steroid treatment for autoimmune pancreatitis. Gut. 2009;58:1504-7.

133. Morselli-Labate AM, Pezzilli R. Usefulness of serum IgG4 in the diagnosis and follow up of autoimmune pancreatitis: $A$ systematic literature review and meta-analysis. J Gastroenterol Hepatol. 2009;24:15-36.

134. Lanzillotta M, Della-Torre E, Milani R, Bozzolo E, BozzallaCassione $E$, Rovati $L$, et al. Increase of circulating memory $B$ cells after glucocorticoid-induced remission identifies patients at risk of lgG4-related disease relapse. Arthritis Res Ther. 2018;20:222.

135. Asano J, Watanabe T, Oguchi T, Kanai K, Maruyama M, Ito T et al. Association between immunoglobulin G4-related disease and malignancy within 12 years after diagnosis: an analysis after longterm followup. J Rheumatol. 2015;42:2135-42.

136. Igawa T, Hayashi T, Ishiguro K, Maruyama Y, Takeuchi M, Takata $\mathrm{K}$, et al. IgG4-producing lymphoma arising in a patient with IgG4-related disease. Med Mol Morphol. 2016;49:243-9.

137. Bledsoe JR, Wallace ZS, Stone JH, Deshpande V, Ferry JA. Lymphomas in IgG4-related disease: clinicopathologic features in a Western population. Virchows Arch. 2018;472:839-52.

138. Hirano K, Tada M, Sasahira N, Isayama H, Mizuno S, Takagi K, et al. Incidence of malignancies in patients with lgG4-related disease. Intern Med. 2014;53:171-6.

139. Inoue D, Yoshida K, Yoneda N, Ozaki K, Matsubara T, Nagai $\mathrm{K}$, et al. IgG4-related disease: dataset of 235 consecutive patients. Medicine (Baltimore). 2015;94:e680.

140. Liao S, Zhang X, Zhu F, Wang Y, Zhu J, Zhang J, et al. Comparison of two subsets of Chinese patients with retroperitoneal fibrosis in terms of lgG4 immunohistochemical staining. Rheumatology (Oxford). 2019;58:455-62.

141. Khosroshahi A, Carruthers MN, Deshpande V, Unizony S, Bloch $\mathrm{DB}$, Stone JH. Rituximab for the treatment of IgG4-related disease: lessons from 10 consecutive patients. Medicine (Baltimore) 2012;91:57-66.

142. Mizushima I, Yamamoto $M$, Inoue D, Nishi S, Taniguchi $Y$, Ubara $Y$, et al. Factors related to renal cortical atrophy development after glucocorticoid therapy in IgG4-related kidney disease: a retrospective multicenter study. Arthritis Res Ther. 2016;18:273.

143. Zhang X, Zhang P, Li J, He Y, Fei Y, Peng L, et al. Different clinical patterns of IgG4-RD patients with and without eosinophilia. Sci Rep. 2019;9:16483.
144. Nishida K, Gion Y, Takeuchi M, Tanaka T, Kataoka TR, Yoshino $T$, et al. Mast cells exhibiting strong cytoplasmic staining for $\lg E$ and high affinity IgE receptor are increased in IgG4-related disease. Sci Rep. 2018:8:4656.

145. Saeki T, Kobayashi D, Ito T, Tamura M, Yoshikawa S, Yamazaki $\mathrm{H}$. Comparison of clinical and laboratory features of patients with and without allergic conditions in IgG4-related disease: a single-center experience in Japan. Mod Rheumatol 2018:28:845-8

146. Zhang PP, Zhao JZ, Wang M, Feng RE, Liu XW, Lai XM, et al. The clinical characteristics of 346 patients with IgG4-related disease. Zhonghua Nei Ke Za Zhi. 2017;56:644-9.

147. Akiyama M, Suzuki K, Yamaoka K, Yasuoka H, Takeshita M, Kaneko Y, et al. Number of circulating follicular helper $2 \mathrm{~T}$ cells correlates with lgG4 and Interleukin-4 levels and plasmablast numbers in IgG4-related disease. Arthritis Rheumatol. 2015;67:2476-81

148. Sanders S, Della Torre E, Perugino CA, Long A, Choi HK, Stone $\mathrm{JH}$, et al. Salivary gland disease in IgG4-related disease is associated with allergic histories [abstract]. Arthritis Rheumatol. 2018;70 (suppl 10).

149. Gao Y, Zheng M, Cui L, Chen N, Wang YN, Zhan YT, et al. IgG4-related disease: association between chronic rhinosinusitis and systemic symptoms. Eur Arch Otorhinolaryngol. 2018;275:2013-9.

150. Culver EL, Vermeulen E, Makuch M, van Leeuwen A, Sadler $\mathrm{R}$, Cargill T, et al. Increased IgG4 responses to multiple food and animal antigens indicate a polyclonal expansion and differentiation of pre-existing B cells in IgG4-related disease. Ann Rheum Dis. 2015:74:944-7.

- Manuscript received March 12, 2020; accepted for publication July 23, 2020.

\section{Iago Carballo Fernández}

Departamento de Medicina Interna

Hospital Clínico Universitario de Santiago

15706 Santiago de Compostela, Spain

E-mail: carballo.iago@gmail.com 